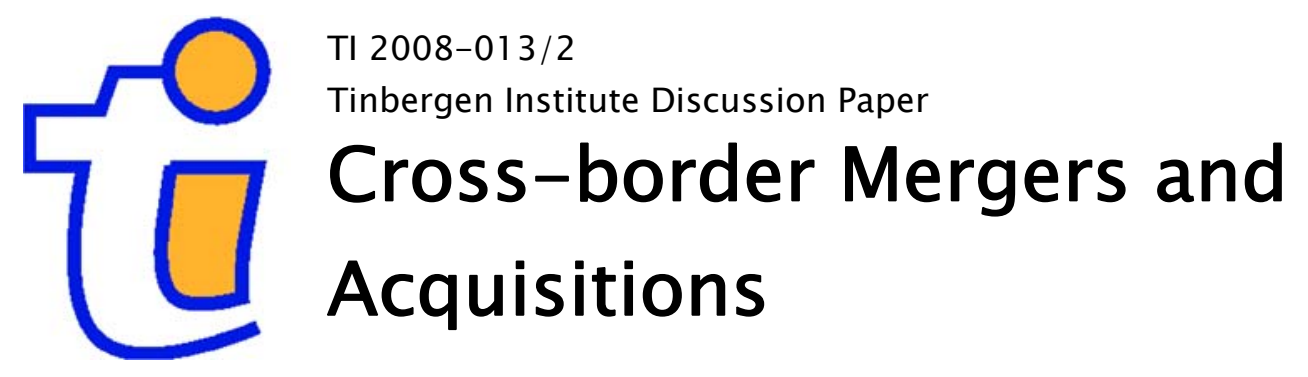

Steven Brakman'

Harry Garretsen²

Charles van Marrewijk ${ }^{3}$

1 University of Groningen;

2 Utrecht University;

${ }^{3}$ Erasmus University Rotterdam, and Tinbergen Institute. 


\section{Tinbergen Institute}

The Tinbergen Institute is the institute for economic research of the Erasmus Universiteit Rotterdam, Universiteit van Amsterdam, and Vrije Universiteit Amsterdam.

Tinbergen Institute Amsterdam

Roetersstraat 31

1018 WB Amsterdam

The Netherlands

Tel.: $\quad+31(0) 205513500$

Fax: $\quad+31(0) 205513555$

Tinbergen Institute Rotterdam

Burg. Oudlaan 50

3062 PA Rotterdam

The Netherlands

Tel.: $\quad+31(0) 104088900$

Fax: $\quad+31(0) 104089031$

Most TI discussion papers can be downloaded at http:/ /www.tinbergen.nl. 


\title{
CROSS-BORDER MERGERS AND ACQUISITIONS: ON REVEALED COMPARATIVE ADVANTAGE AND MERGER WAVES
}

\author{
by \\ STEVEN BRAKMAN ${ }^{1}$ \\ University of Groningen \\ HARRY GARRETSEN \\ Utrecht University \\ CHARLES VAN MARREWIJK \\ Erasmus University Rotterdam
}

This version: January 2008

\begin{abstract}
By combining two large data sets (on international trade flows and cross-border mergers and acquisitions - M\&As), we test two implications of Neary’s (2003, 2007) general oligopolistic equilibrium (GOLE) model (incorporating strategic interaction between firms in a general equilibrium setting). In terms of economic importance, the dominant merger wave variable is a positive global-all effect, indicating that M\&A waves are an economy-wide, global phenomenon. Country-specific merger wave variables are of secundary importance. In accordance with the bilateral GOLE model as specified by Neary, we find strong evidence that acquiring firms operate in strong sectors. However, we also find (less pronounced) evidence that target firms are active in strong, not weak sectors, which we label the 'target paradox'. We show how a multi-country extension of the GOLE model that allows for firm heterogeneity can explain this target paradox.
\end{abstract}

Keywords: Comparative Advantage, Cross-border Mergers and Acquisitions, Merger Waves, General Oligopolistic Equilibrium Trade Model.

JEL code: F10, F12, L13

\footnotetext{
${ }^{1}$ We would like to thank Ralph Bayer, Carel Eijgenraam, Peter Neary, Richard Pomfret, Christis Tombazos, and seminar participants at the University of Adelaide, Monash University, and the Tinbergen Institute for useful comments and suggestions. We thank Utz Weitzel for useful suggestions and for his help with the Thomson data. Please send all correspondence to s.brakman@rug.nl, Faculty of Economics, P.O. Box 800, 9700 AV, Groningen, The Netherlands.
} 


\section{Introduction}

Cross border mergers and acquisitions (M\&As) are a main vehicle for foreign direct investment (see Barba Navaretti and Venables, 2004, and Table 1 below; Evenett, 2004 provides a survey). Yet despite its quantitative importance, the determinants of cross-border M\&As are still not well-understood. Following Neary (2007) various motives for M\&As can be distinguished in general. In the Industrial Organization (IO) literature two basic motives stand out: an efficiency motive and a strategic motive. Efficiency gains arise because $M \& A s$ increase synergy between firms through increased use of economies of scale or scope. Furthermore, from a strategic perspective M\&As might change the market structure and as such have an impact on firm profits, which might even be reduced to zero (this is the so-called 'merger paradox', Salant et al., 1983). ${ }^{2}$

Kuemmerle (1999) analyzes FDI in R\&D for the pharmaceutical and electronics sectors with respect to exploiting existing or building up new firm-specific advantages. Hejazi and Safarian (1999) consider the role of trade and FDI as diffusion channels for total factor productivity growth and conclude that FDI is likely to be more important. The role of cultural distance, based on the Kogut and Singh (1988) index compiled from the Hofstede (1980) cultural dimensions, on FDI flows has been frequently analyzed, see Shenkar (2001) for an overview and critical discussion and Garita and van Marrewijk (2008) for a more comprehensive modern approach for M\&As. Reuer, Shenkar, and Ragozzino (2004) analyze the sector-specific contractual heterogeneity of cross-border M\&As to mitigate the problem of adverse selection, while Björkman, Stahl, and Vaara (2007) discuss the role of cultural differences on capability transfer for cross-border acquisitions. Dikova and van Witteloostuijn (2007) analyze the influence of institutions on entry and establishment mode choices in transition countries. Of particular interest for our study is Bertrand and Zitouna's (2006) partial equilibrium Cournot analysis of differences in technology (and thus production costs) on incentives to merge in relation to fixed costs. They find that for

\footnotetext{
${ }^{2}$ This result can be understood as follows. In a symmetric Cournot setting a merger initially increases industry concentration and therefore industry profits (the merging firms tend to reduce output in order to increase profits). In a Cournot setting, however, other firms react by increasing output, which harms the firms involved in the merger with the result that, in the benchmark case of Salant et al (1983), the induced expansion of output by the uninvolved firms is sufficient to reduce the profits of the acquiring firm. As usual, strategic outcomes depend on the type of strategic interaction, form of demand schedules, and of the type of game that is played (see Neary, 2004).
} 
high firm-level fixed costs the high-technology firm will take over the low-technology firm for low enough costs of firms' integration. For low and high technology gaps there is an inverted U-shaped relation between trade costs and incentives to merge. For medium technology gaps this is inverted W-shaped.

The problem with these explanations is that they are based on partial equilibrium models and usually do not deal explicitly with cross-border M\&As. The partial modeling of M\&As provides a fundamental, but also a limited understanding of this form of takeover, as cross-border mergers are most likely related to economy-wide shocks such as economic integration, changes in the legal and regulatory environment, or possible asymmetric business cycles. Factors like these change the position of one country relative to another, and point in the direction of standard trade theories rather than to the more partial oriented IO models. The standard general equilibrium trade theories, however, are not well equipped to explain M\&As because these theories mostly combine no barriers to entry and the absence of strategic interaction which effectively precludes the analysis of M\&As. This not only holds for the neo-classical perfect competition trade models, but also for the models based on increasing returns to scale and monopolistic competition. The latter is forcefully brought forward by Neary (2004, 2007), but also by the founding fathers of the second monopolistic competition revolution themselves, see Dixit (2004) and Stiglitz (2004).

The model developed by Neary (2003, 2007) combines general equilibrium trade theory with imperfect markets and strategic behavior between firms. This is difficult, because pricing decisions of large firms not only directly affect profits, but their market (pricing) behavior also affects national income and the real income of their customers. Furthermore, large firms could also influence factor prices. Neary's (2003) General Oligopolistic Equilibrium (GOLE) model avoids some of the standard pitfalls of modeling oligopolistic markets by assuming that firms are large in their own markets but small in the economy as whole and by simultaneously allowing for strategic interaction between firms. Thus firms do not have to calculate the full general equilibrium of the whole economy. For our present purposes it is interesting that cross-border M\&As can occur in this model, and that one can derive testable hypotheses on cross-border M\&As in relation to comparative advantage. Firms that have a comparative (cost) advantage have an incentive to merge with or acquire other 
firms. If these (sector-specific) cost differences are economy-wide, the model explains cross-border M\&As. Furthermore, the model also explains the well-established stylized fact that M\&As come in waves. An initial M\&A makes the next one more attractive (in terms of firm profitability) which leads to M\&A waves.

The aim of our paper is to test two implications of the Neary model (and thus not the model itself), in particular whether (i) comparative advantage helps to explain the direction of individual cross-border M\&As and (ii) M\&A waves are an important determinant of individual cross-border M\&As. The second implication is not unique to the Neary model and has been a subject of frequent study, see the discussion below and in section 3. The first implication is also supported by Bertrand and Zitouna's (2006) partial equilibrium approach.

To test the two implications, we combine two large data sets: the bilateral trade data compiled by Feenstra et al. (2005) and the global mergers and acquisitions database of Thomson Financial Securities Data. The trade data allow us to identify country- and sector-specific measures of revealed comparative advantage using the Balassa index. This index measures the share of a sector's exports in the overall country-wide exports, compared to the share of that sector's export in the total exports of a group of reference countries (Balassa, 1989). The Thomson data give us for the period 19802005 firm-specific data on cross-border M\&As. To test our main hypotheses, which will be further (sub-) classified below, we take as our M\&A sample all cross-border M\&As to and from Australia, France, USA, UK and the Netherlands. This selection was based on cross-border M\&A activity, geographical spread, and variety in country size. Though the two main hypotheses (i) and (ii) above are key features of the Neary model, we want to stress that we neither claim to test all implications of the model nor do we claim that the two hypotheses are necessarily unique to the Neary model. As to the former, we do not look into the model's implication that firm profitability increases after the M\&A takes place. As to the latter, our paper is not the first to test for merger waves. However, the combination of the two hypotheses captures the essence of Neary's GOLE model, and to our knowledge the present paper is the first attempt to test for these key implications. 
Our main new findings are as follows: (i) in terms of economic importance, the dominant merger wave variable is a positive global-all effect (indicating that M\&A waves are an economy-wide, global phenomenon), (ii) country-specific merger wave variables are of secundary economic importance, (iii) in accordance with the bilateral GOLE model we find evidence that acquiring firms operate in strong sectors, (iv) in contrast to the bilateral GOLE model we also find (less pronounced) evidence that target firms are active in strong sectors ('target paradox'), and (v) we show that a multi-country extension of the GOLE model allowing for firm heterogeneity can explain the target paradox.

The paper is organized as follows. Section 2 briefly describes some stylized facts on cross-border M\&As. Section 3 summarizes the model developed by Peter Neary and highlights the two main hypotheses, divided into 6 sub-hypotheses to be tested in this paper. Section 4 introduces and discusses the two data sets. Section 5 discusses the estimation procedure. Sction 6 presents our main empirical findings. Section 7 explains the target paradox. Section 8 discusses the robustness of our results, while section 9, finally, summarizes and concludes.

\section{Cross-border mergers and acquisitions: some facts}

Table 1 shows that cross-border M\&As constitute a main vehicle for FDI, especially for FDI flows to developed countries. Also, if one looks at cross-border M\&As as a share of total M\&A activity, it is clear that cross-border M\&As are quite important.

During, for instance, the period 1987-1999, which captures most of the so-called $4^{\text {th }}$ and $5^{\text {th }}$ merger wave, cross-border M\&As, on average, made up for about $25-30 \%$ of total M\&A activity in terms of both the value and the number of the transactions (Schenk, 2002). As Table 1 suggests, cross-border M\&As are particularly relevant within the group of developed countries. OECD data show that, measured as a share of their national GDP, the UK and the Netherlands, followed by Germany and France, are the leading countries in cross-border M\&As. Firms from these countries are most active in acquiring (stakes in) firms in other countries. At the peak of the $5^{\text {th }}$ merger wave in the late 1990s, for instance, cross-border M\&As (as a percentage of GDP) were $16.3 \%$ in the UK and $13.7 \%$ in the Netherlands. 
Table 1 Cross-border M\&A investments (percent of FDI inflows to the host countries)

\begin{tabular}{l|cccc}
\hline \hline & $1987-91$ & $1992-94$ & $1995-97$ & $1998-2001$ \\
\hline World & 66.29 & 44.75 & 60.18 & 76.23 \\
Developed countries & 77.49 & 64.93 & 85.39 & 88.96 \\
Developing and transition economies & 21.94 & 15.49 & 25.79 & 35.74 \\
\multicolumn{2}{l}{ Source: Barba-Navaretti and Venables (2004, p.10). } & & &
\end{tabular}

To date, the best and most extensive data source for M\&As is the Global Mergers and Acquisitions database of Thomson Financial Securities Data (Thomson, hereafter). Thomson gathers information on M\&As exceeding 1 million US dollar. Its main sources of information are financial newspapers and specialized agencies like Bloomberg and Reuters. Our Thomson data set begins in 1979 and ends in April 2005. It should be kept in mind that until the mid-1980s Thomson focused very much on M\&As for the USA only, and it is only for about the last 20 years that (systematic) M\&A data gathering took place for other (developed) countries. For more information on the specifics of the Thomson data set we used for our analysis, see section 4 .

Gugler, et al. (2003) use the Thomson M\&A data base for the period 1981-1998 and provide the summary statistics on which Table 2 is based. For each country (group) Table 2 gives the number of M\&A deals, the average deal value (in millions of US \$) and the percentage of cross-border M\&As. The table illustrates the dominant position of the USA in terms of the number of M\&A deals (which is partly a reflection of the initial US-bias in the Thomson data set). At the same time it is clear that for crossborder M\&As, continental Europe and the UK outstrip the USA. The relatively high share of cross-border M\&As in Europe reflects the fact that the process of European economic integration has stimulated cross-border M\&A activity. The relative importance of cross-border M\&A is even larger for Japan, but the overall number of deals is rather low. Gugler et al. (2003) also show for their sample that on average the profit rate of the acquiring firm is higher than for the target firm (which can be interpreted as evidence for productivity differences). The main point is that crossborder M\&As make up a large part of total M\&A activity. A similar conclusion is reached by Rossi and Volpin (2004), who use the cross-border M\&A ratio, the 
percentage of completed M\&A deals in which the acquirer is from a different country than the target. For their sample of 49 countries (based on the Thomson data set), the cross-border ratio is on average about 43 percent. See Brakman, Garretsen, and van Marrewijk (2007) for a recent empirical overview of cross-border M\&As.

Table 2 Summary statistics on M\&As for selected countries, 1981-1998

\begin{tabular}{l|ccc}
\hline \hline & $\begin{array}{c}\text { Number of deals } \\
\text { (thousands) }\end{array}$ & $\begin{array}{c}\text { Average deal value } \\
\text { (million US \$) }\end{array}$ & $\begin{array}{c}\text { Percent } \\
\text { cross-border }\end{array}$ \\
\hline USA & 21.148 & 246.7 & 10.6 \\
UK & 4.717 & 158.3 & 29.9 \\
Continental Europe & 9.595 & 285.9 & 33.5 \\
Japan & 0.646 & 464.9 & 52.6 \\
Australia / New & 3.232 & 156.0 & 30.0 \\
Zealand / Canada & & & 28.5 \\
Rest of the World & 5.262 & 128.3 &
\end{tabular}

Finally, there is one important stylized fact as to the development of M\&A activity over time: they come in waves. It is common to distinguish between five merger waves during the $20^{\text {th }}$ century, three of which are recent (Andrade, et al., 2001). The $3^{\text {rd }}$ wave took place in the late 1960 -early 1970 s, the $4^{\text {th }}$ wave ran from about the mid 1980s until 1990, and the $5^{\text {th }}$ wave started around 1995 and ended in 2000 with the collapse of the "New Economy" and it seems that right now a $6^{\text {th }}$ wave is in the making. Merger waves are very much (positively) correlated with increases in share prices and p/e ratios and with the overall business cycle in general. When one sticks to standard M\&A motives, like the efficiency argument, it is rather difficult to explain the synchronicity of M\&As. Interestingly, Gugler, et al. (2004) find that merger waves can be understood if one acknowledges that M\&As do not boost efficiency and hence do not increase shareholders' wealth, but instead find that M\&A waves are best looked upon as the result of overvalued shares and managerial discretion. In section 4 we will see if M\&A waves are also present in the data when one only looks at crossborder M\&As. For the case of the USA and restricting their sample to firms that are publicly traded, Andrade et al. (2001) show that with each merger wave the value of the M\&A deals (measured by firms’ market capitalization) increases strongly. Merger 
waves in Europe seem to follow those in the USA with a short lag, and until the most recent (completed) merger wave, the number and value of M\&A deals during these waves fell short compared to those in the US counterpart. But during the $5^{\text {th }}$ merger wave, European firms engaged in a number of (mega) M\&As with the cross-border take-over of Mannesmann (Germany) by Vodafone (UK) for 172 billion US\$ in 2000 as to date the largest M\&A in Europe. These facts are clearly interesting, but they do not tell us much about the motives for M\&As. The next section therefore presents a model that explains cross-border M\&As.

\section{A model of mergers and acquisitions: GOLE}

In this section we give a brief summary of the general oligopolistic equilibrium (GOLE) model and formulate the central hypotheses that we will test. ${ }^{3}$ We distinguish between two countries: Home and Foreign, where an asterisk denotes Foreign variables when appropriate. Suppose there is a continuum of sectors indexed by $z \in[0,1]$ in which there are by assumption $n$ domestic firms with unit costs $c(z)$ and $n^{*}$ foreign firms with unit costs $c^{*}(z)$ that engage in Cournot competition. ${ }^{4}$ Consumers maximize preferences subject to a budget constraint, see equation (1), where $U$ is utility, $I$ is income, $p(z)$ is the price of $\operatorname{good} z$, and $\bar{x}(z)$ is the demand for good $z$. If we let $\lambda$ denote the marginal utility of income (the Lagrange multiplier), then $p(z)=(1 / \lambda)[\bar{a}-\bar{b} \bar{x}(z)]$ gives the demand for good $z$ in Home. The quadratic specification allows perfect aggregation over different countries, so the simple total demand function is given in (2), where $x(z) \equiv \bar{x}(z)+\bar{x}^{*}(z)$, $a \equiv\left(\bar{a}+\bar{a}^{*}\right) /\left(\lambda+\lambda^{*}\right)$, and $b \equiv \bar{b} /\left(\lambda+\lambda^{*}\right)$. Note that firms are large in their own sector, where they behave strategically, but small relative to the economy as a whole.

$$
\max U=\int_{0}^{1}\left[\bar{a} \bar{x}(z)-(1 / 2) \bar{b} \bar{x}(z)^{2}\right] d z ; \quad \text { s.t. } \quad \int_{0}^{1} p(z) \bar{x}(z) d z \leq I
$$

$$
p(z)=a-b x(z)
$$

\footnotetext{
${ }^{3}$ A complete description and derivation of the model is given in Neary $(2003,2007)$.

${ }^{4}$ For now we take the unit costs as given, but they are determined in general equilibrium. There are no fixed costs of production as these provide a well-known incentive for M\&As, see Bertrand and Zitouna (2006)
} 
The first order condition for profit maximization for a firm active in sector $z$ is equal to: $p(z)-c(z)=b y(z)$, where $y(z)$ is the firm's supply. From this it follows directly that the firm's profits, $\pi$ say, are proportional to the square of output $\pi=b y(z)^{2}$. In equilibrium, the output for domestic and foreign firms will depend on the number of competitors, the unit costs, and the parameters. Using the first order conditions and equating total supply and demand in the market we can determine a firm's output: ${ }^{5}$

$$
y\left(n, n^{*} \mid c, c^{*}, a, b\right)=\frac{\left(n^{*}+1\right)(a-c)-n^{*}\left(a-c^{*}\right)}{b\left(n+n^{*}+1\right)}
$$

Figure 1. Comparative advantage and production

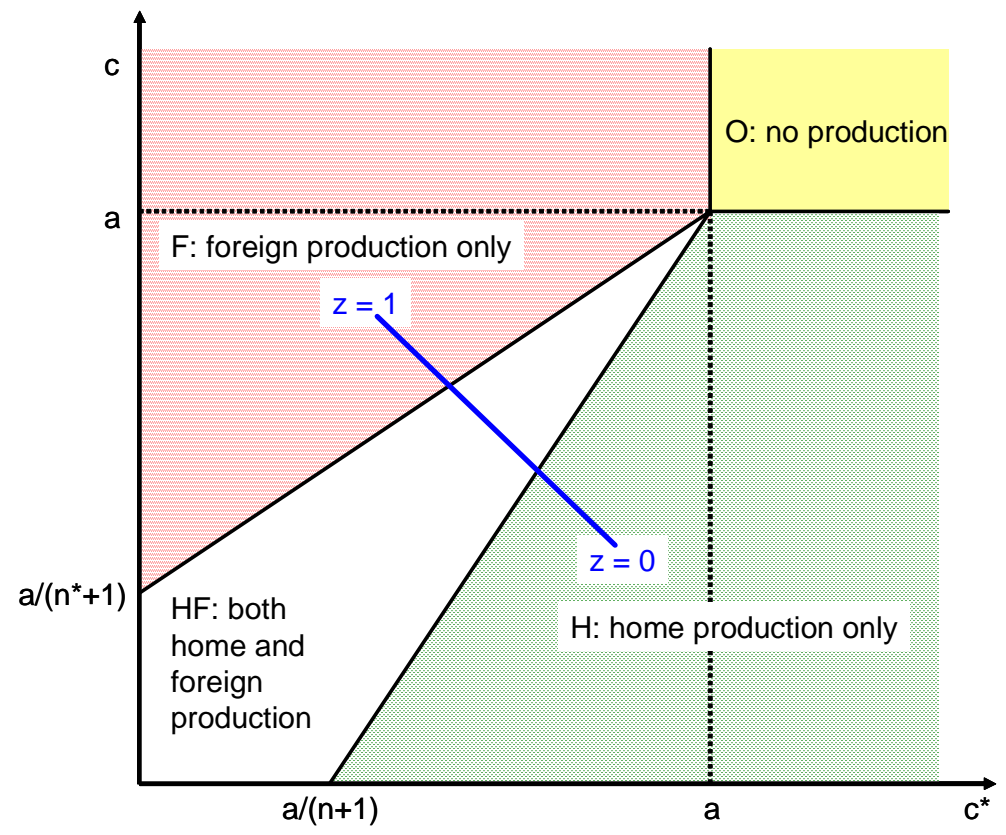

Figure 1 summarizes the situation in a two country setting for all markets. The axes depict marginal costs in both countries. From (3) we see that domestic firms have a positive output level only if their costs are below a weighted average of the demand intercept and the foreign firm's costs: $c<\xi_{0} a+\left(1-\xi_{0}\right) c^{*}$, with $\xi_{0} \equiv 1 /\left(1+n^{*}\right)$. This condition divides the cost area in Figure 1 in four regions. If costs are too high for both firms, there is no production (area O). If domestic costs are much higher than foreign costs, only foreign firms will produce (area F). If foreign costs are much higher than domestic costs, only domestic firms will produce (area $\mathrm{H}$ ). If domestic

\footnotetext{
${ }^{5}$ Similarly for a foreign firm.
} 
and foreign costs are neither too high nor too different, both domestic and foreign firms will produce (area HF). Comparative advantage is most easily incorporated using a Ricardian model based on Dornbusch et al. (1977). If labor is the only input and $\alpha(z)$ is the unit labor requirement in sector $z$, unit costs are simply given by $c(z)=w \alpha(z)$, where $w$ is the wage rate. If we now rank the sectors such that the Home country is efficient in sectors with a low value of $z$, as indicated by the $z z$-line in Figure 1, the domestic firms will be the only producers for low values of $z$, both countries will be active for intermediate values of $z$, and the foreign firms will be the only producers for high values of $z$. ${ }^{6}$ The cut-off values will be determined in general equilibrium by the labor market clearing conditions. Note in particular that the $z z$-line will shift in response to changes in the wage rates.

We can now analyze the profitability of mergers and acquisitions within this model. Let " 1 " and " 0 " indicate the post- and pre-merger situation, respectively. Then the gain of taking over a Home firm, $G_{H}$ say, for a foreign firm is given by:

$$
G_{H}=\left[\pi_{1}^{*}(n-1, n * .)-\pi_{0}^{*}(n, n * \mid .)\right]-\pi_{0}(n, n * .)>0
$$

The first term (in square brackets) relates to the gain in profitability from reduced competition by taking over the domestic firm. The second term indicates the cost of acquiring the domestic firm, equal to compensating the owners for their profit loss. Since the cost of acquiring the domestic firm is small if this firm has high costs, leading to a low output and profit level (see equation 3), it pays to take over a domestic firm if you have a cost advantage. On the other hand, the cost advantage should not be too big, because otherwise there are no active foreign firms to take over. Neary (2007) therefore shows that M\&As take place at the borders of the FH area in Figure 1, enlarging the areas in which only domestic or only foreign firms are active.

\footnotetext{
${ }^{6}$ Note that the zz-line could be a curve instead of a line, but this is not material to our discussion.
} 
Figure 2 Comparative advantage and $M \& A s$

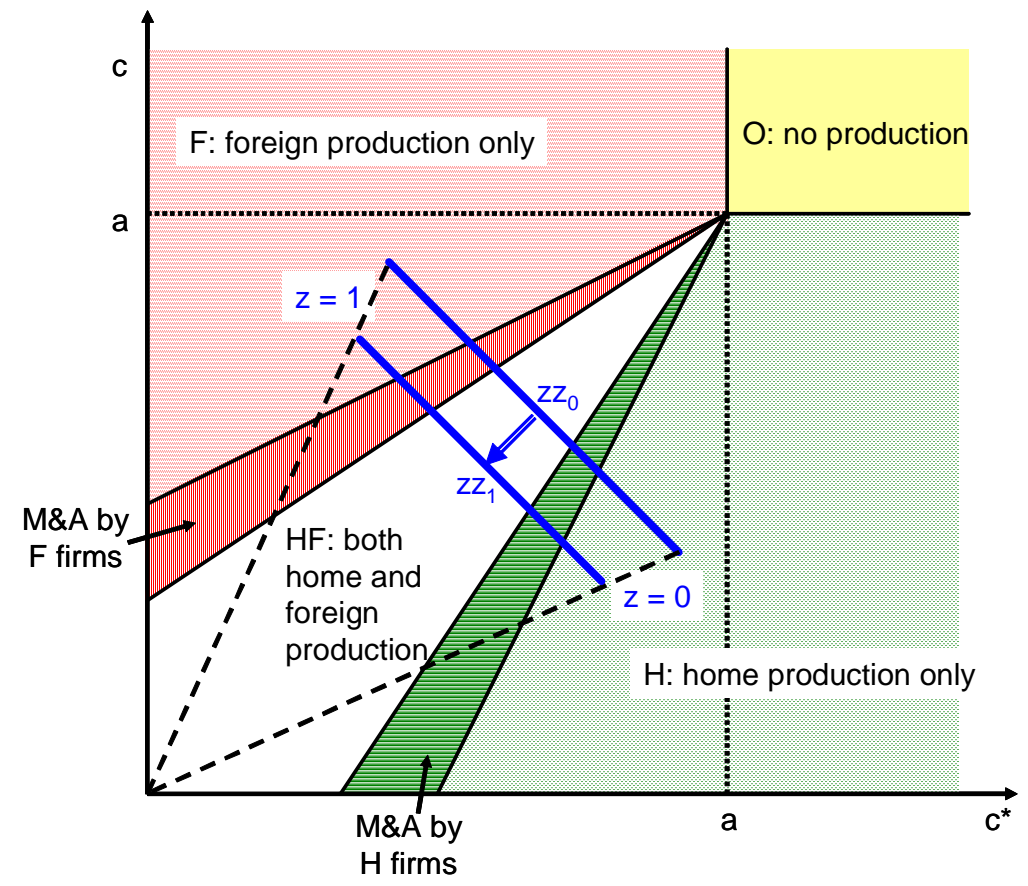

It turns out that (4) holds if domestic costs are above a weighted average of the demand intercept and the foreign costs: $c>\xi_{1} a+\left(1-\xi_{1}\right) c^{*}$, with $0<\xi_{1}<\xi_{0}{ }^{7}$ This determines the shaded areas in Figure 2 where it is profitable to take over other firms, namely if strong firms take over weaker firms. For ease of exposition the general equilibrium consequences of allowing for M\&As are illustrated for two symmetric countries in Figure 2. The $\mathrm{zz}_{0}$ line indicates the distribution of costs and sectors at the initial trade equilibrium, before M\&As are possible. Once these are allowed, the M\&As cause profits to increase and the demand for labor and the wage rate to fall. This leads to the inward shift of the $z z$ curve from $z z_{0}$ to $z z_{1}$. Evidently, this general equilibrium effect influences the range of firms actually taken over and the distribution of sectors specializing either completely or incompletely, but it does not change any of the main implications of the model.

This completes the summary of the model. We now turn to our hypotheses. As we explained in the introduction, weak and strong firms will be identified at the countrysector level by the well-known notion of revealed comparative advantage as

${ }^{7} \xi_{1} \equiv \frac{\left[2 n N+\left(n^{*}+1\right)\left(N^{2}-1\right)\right]-\left[2(n+1) N+n^{*}\left(N^{2}-1\right)\right]}{\left[2 n N+\left(n^{*}+1\right)\left(N^{2}-1\right)\right]} ; \quad N \equiv n+n^{*}$, see Neary (2007). 
frequently used in the empirical international trade literature. This leads to the following first two hypotheses:

Hypothesis 1-A

Acquiring firms operate in sectors with a high revealed comparative advantage (as measured by the Balassa index).

Hypothesis 1-B

Target firms operate in sectors with a low revealed comparative advantage (as measured by the Balassa index).

These two hypotheses, based on the GOLE model outlined above, have not been tested before and lie at the heart of the GOLE model. Our other hypotheses involve the phenomenon of mergers waves, which is already well-established empirically see for example Evenett (2004). There are alternative theoretical explanations for this phenomenon, see for example Gorton, Kahl, and Rosen (2005) who argue that a technological or regulatory change can induce a preemptive wave of defensive acquisitions. ${ }^{8}$ Within the Neary framework, the crucial point to note regarding equation (4) on the profitability of M\&As is: (i) that non-participating firms also benefit from the takeover through a reduction of competition, and (ii) an M\&A increases the profitability, and thus attractiveness, of the next M\&A. This leads to a 'wait and see' or 'after you' effect which Neary, using a game-theoretic setting, translates into a theory of merger waves. Even though we are thus not the first to look into the empirics of merger waves, the testing for M\&A waves is relevant for two main reasons. The first one is that in conjunction with hypotheses 1-A,B the testing for merger waves provides a stronger test of the underlying model. The second reason is that the detailed structure of our data allows us to be more specific than related work about the characteristics of the merger waves, since we can identify the number of M\&As in the past one or two years at the sector level for all countries (Hypothesis 2-A below), at the aggregate level for all countries (Hypothesis 2-B below), at the sector level for the acquiring or target country itself ((Hypothesis 2-C below), and,

\footnotetext{
${ }^{8}$ Fridolfsson and Stennek (2005) argue that M\&As may reduce profits if being an 'insider' is better than being an 'outsider'. In general, they show the difficulty of accurately predicting M\&A profitability.
} 
finally, at the aggregate level for the acquiring or target country (Hypothesis 2-D below). It shoudl be noted that Neary focuses on global waves.

$\underline{\text { Hypothesis 2-A }}$

Mergers and acquisitions come in global, sector-specific waves

Hypothesis 2-B

Mergers and acquisitions come in global waves for all sectors

Hypothesis 2-C

Mergers and acquisitions come in country-and sector-specific waves

Hypothesis 2-D

Mergers and acquisitions come in country-specific waves for all sectors

\section{Cross-border M\&A data and trade data}

\subsection{M\&A characteristics}

The Thomson data set allows us to analyze cross-border M\&As for a large range of countries and years. After some preliminary investigations, we decided to restrict our analysis to cross-border merger deals in the period 1980 - early 2005 for five of the most active countries, varying in size and geographic location, namely Australia (AUS), France (FRA), the Netherlands (NLD), the United Kingdom (GBR), and the United States (USA), see also section 2. ${ }^{9}$ This resulted in 11,721 observations, or about 28.5 per cent of all cross border M\&As, as summarized in Table 3. The USA was the most active country (40.3 percent of the acquisitions and 43.7 percent of the targets), closely followed by the UK (39.5 and 27.6 percent, respectively). Note that cross-border M\&As with acquirer and target located in the same country are possible, for example when an American firm takes over another American firm that is active abroad. ${ }^{10}$ Our main analysis includes these within-country cross-border M\&As as classified by Thomson and show in section 8.2 that our results are robust if these observations are excluded from the data. ${ }^{11}$

\footnotetext{
${ }^{9}$ At this stage we included all cross border M\&As with a value above $\$ 1$ million between January $1^{\text {st }}$ 1979 and April $4^{\text {th }} 2005$ where the acquirer and target were located in one of the countries above. For this period the Thomson data set gives a total of 159,791 completed M\&A deals. Of these deals a total of 41,106 are cross-border M\&As. Restricting the cross-border M\&As for both acquirer and target firm to the USA, UK, The Netherlands, Australia, and France finally gives the 11,721 observations on crossborder M\&As used in our analysis.

${ }^{10}$ The majority of within-country M\&As is not classified as cross-border by Thomson, so not included.

${ }^{11}$ The obvious drawback of this restriction is that it reduces the number of observations, see also subsection 6.3 wich focuses on horizontal M\&As only. .
} 
Table 3 Overview of mergers and acquisitions; all sectors, 1980-2005

\begin{tabular}{|c|c|c|c|c|c|c|c|}
\hline & & \multicolumn{5}{|c|}{ Acquirer } & \multirow[b]{2}{*}{ Sum } \\
\hline & & AUS & FRA & USA & GBR & NLD & \\
\hline \multicolumn{8}{|c|}{ \# of M\&As } \\
\hline \multirow[t]{6}{*}{ Target } & AUS & 562 & 23 & 388 & 351 & 26 & 1,350 \\
\hline & FRA & 14 & 223 & 425 & 608 & 74 & 1,344 \\
\hline & USA & 231 & 310 & 2,136 & 2,229 & 213 & 5,119 \\
\hline & GBR & 137 & 249 & 1,602 & 1,095 & 154 & 3,237 \\
\hline & NLD & 13 & 52 & 178 & 351 & 77 & 671 \\
\hline & Sum & 957 & 857 & 4,729 & 4,634 & 544 & 11,721 \\
\hline \multicolumn{8}{|c|}{ per cent } \\
\hline & AUS & 4.8 & 0.2 & 3.3 & 3.0 & 0.2 & 11.5 \\
\hline & FRA & 0.1 & 1.9 & 3.6 & 5.2 & 0.6 & 11.5 \\
\hline & USA & 2.0 & 2.6 & 18.2 & 19.0 & 1.8 & 43.7 \\
\hline & GBR & 1.2 & 2.1 & 13.7 & 9.3 & 1.3 & 27.6 \\
\hline & NLD & 0.1 & 0.4 & 1.5 & 3.0 & 0.7 & 5.7 \\
\hline & Sum & 8.2 & 7.3 & 40.3 & 39.5 & 4.6 & 100 \\
\hline \multicolumn{5}{|c|}{ Horizontal M\&As (2-digit sic level): } & 5,628 & \multicolumn{2}{|c|}{ (48.0\%) } \\
\hline \multicolumn{5}{|c|}{$100 \%$ acquired in M\&A } & 8,487 & \multicolumn{2}{|c|}{$(72.4 \%)$} \\
\hline \multicolumn{5}{|c|}{$100 \%$ owned after M\&A } & 9,007 & \multicolumn{2}{|c|}{ (76.8\%) } \\
\hline \multirow{3}{*}{\multicolumn{4}{|c|}{ Value of transaction (million \$): }} & mean & & & 186.17 \\
\hline & & & & median & & & 20.00 \\
\hline & & & & maxim & & & $0,286.67$ \\
\hline
\end{tabular}

About 48 per cent of cross-border M\&As can be classified as horizontal M\&As at the 2-digit level where we define a horizontal M\&A as an M\&A where the acquiring and target firm belong to the same 2-digit sector. This classification has its obvious limitations as it assumes an SIC2 industry can be looked upon as a sector. Our main analysis includes all cross-border M\&As. Since the Neary model focuses on horizontal M\&As we show in section 8.1 that our results are robust if only horizontal 
M\&As are included. ${ }^{12}$ In most cases the M\&A is a complete takeover (72.4 percent) or results in a complete takeover (76.8 percent). The distribution is very skewed and very close to a log-normal distribution, with a mean value of $\$ 186$ million and a median value of \$20 million.

\subsection{Concordance}

Since we want to investigate to what extent (revealed) comparative advantage (as measured by the Balassa index) determines individual M\&As, we have to make a connection between the sectors as identified by SIC code in the Thomson data base and trade data which allows us to calculate the Balassa index. For the latter, see subsection 4.3 below, we use the database from Feenstra et al. (2005) which provides trade data between countries by commodity, classified by SITC (revision 2). So we have to match M\&A data, classified by one code, with trade data, classified by another code. As a first step, a concordance between SITC (revision 2) and the international industrial classification ISIC (revision 2) is applied. ${ }^{13}$ The next step is to apply a concordance between ISIC (revision 2) and the SIC87 industrial classification, which is the classification used in the Thomson M\&A database. This concordance, from 3-digit ISIC (revision 2) industries to 2-digit SIC87 industries, is based on a matching of industry names. Since SIC87 was initially derived from ISIC (revision 2), this matching was fairly straightforward. ${ }^{14}$

The above exercise results in 20 sectors for which we have reliable trade data (and thus information on revealed comparative advantage), see Figure 3. A complete list of countries and SIC-sectors in our sample can be found in Appendix I. Finally, we restricted our set of M\&A observations to those sectors for which both acquirer and target are an element of the concordance subset $\left(I^{\prime}\right)$, see sub-section 4.3 below. This reduced the number of observations to 3,462, with the summary information as given in Table 4. Note that, as a result of this restriction, the share of horizontal M\&As increases (from 48.0 to 64.5 percent), as did the share of complete takeovers (from

\footnotetext{
12 The obvious drawback of the restriction to within-sector M\&As is that it reduces the number of observations.

${ }^{13}$ For this concordance, see: http://www.macalester.edu/research/economics/PAGE/HAVEMAN/Trade.Resources/Concordances/Fr omSITC/sitc2.isic2.txt

${ }^{14}$ This concordance is available upon request.
} 
76.8 to 86.3 percent complete ownership after the M\&A), see also section 8 . There is very little effect on the value distribution of M\&As (which is still log-normal).

Table 4 Overview of M\&As; concordance subset ( $\left.I^{\prime}\right), 1980-2005$

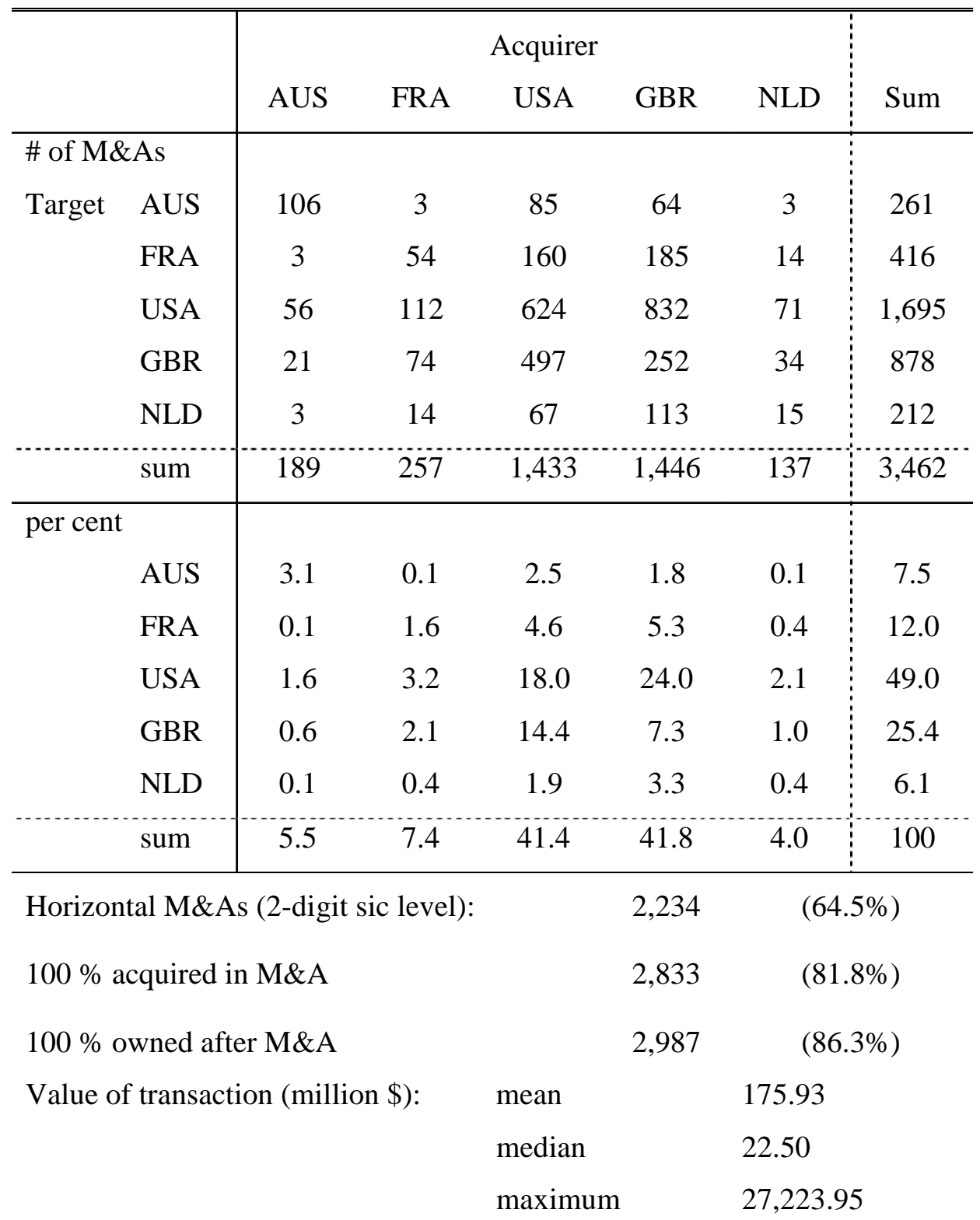

Figure 3 depicts the distribution of the number of M\&As over the various sectors of the concordance subset $I^{\prime}$. In general, the correlation between targets and acquirers for a sector is high, which is not too surprising in view of the high share of horizontal M\&As. The most active sectors are SIC 28 (Chemicals), SIC 36 (Electronics), SIC 35 (Ind. machinery), SIC 38 (Instruments), and SIC 20 (Food). Foreshadowing our 
estimation results, we should point out here that, as Figure 3 suggests is the case for most sectors, a high correlation between the number of targets and acquirers is not in itself evidence that all/ most cross-border M\&As are intra-industry.

Figure 3 Sector distribution of M\&As, concordance subset I', 1980-2005

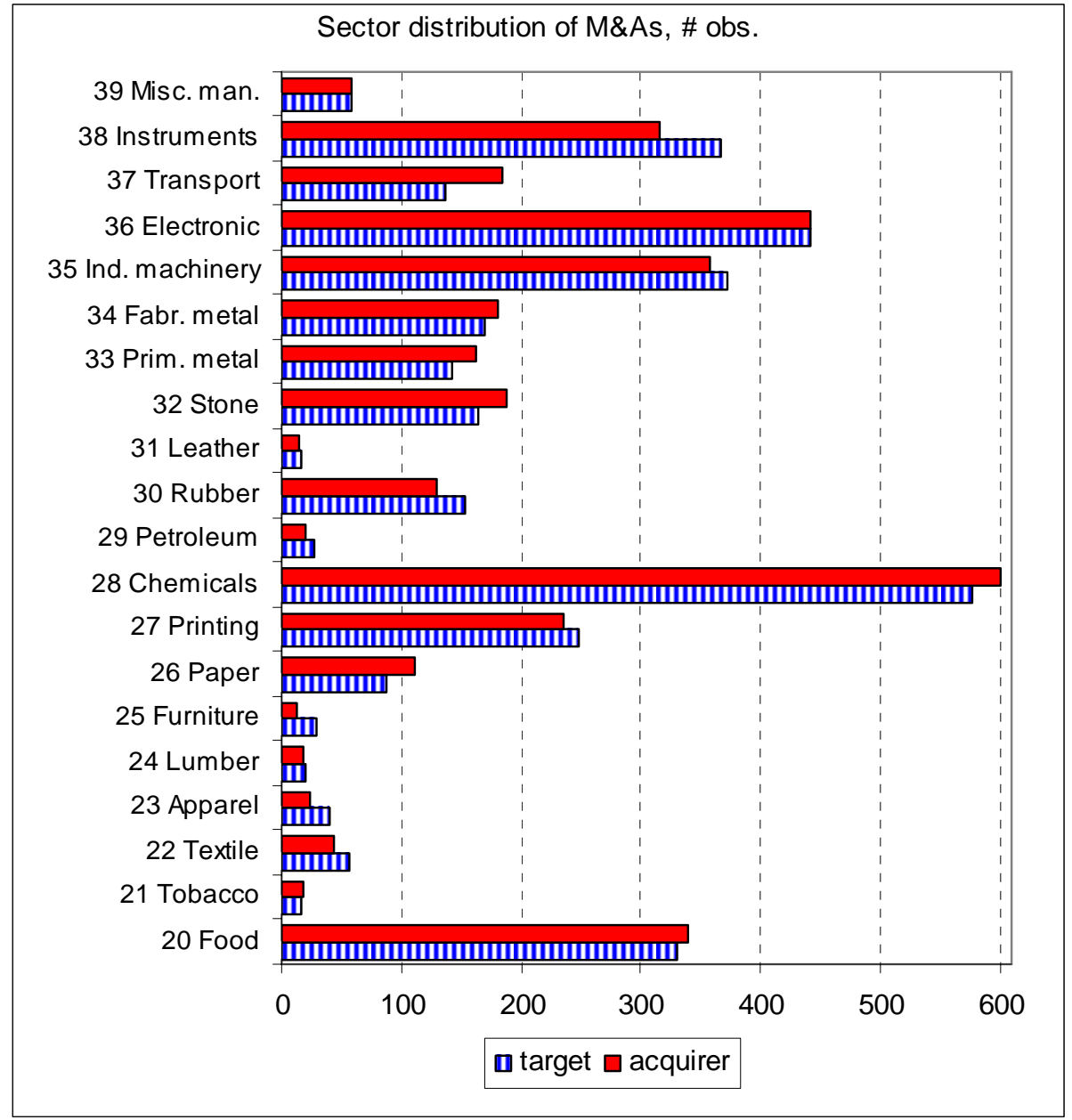

The figure gives brief sector descriptions only; see Appendix I for details.

\subsection{Balassa index characteristics}

Let $X_{i, t}^{j}$ denote the value of exports of sector $i \in I$ from country $j \in J$ in period $t \in T$. Then the Balassa index $B I_{i, t}^{j}$ of revealed comparative advantage is defined as

$$
B I_{i, t}^{j} \equiv \frac{X_{i, t}^{j} / X_{t}^{j}}{X_{i, t} / X_{t}} ; \quad \text { where } X_{t}^{j} \equiv \sum_{i} X_{i, t}^{j} ; X_{i, t} \equiv \sum_{j} X_{i, t}^{j} ; X_{t} \equiv \sum_{i} \sum_{j} X_{i, t}^{j}
$$

If $B I_{i, t}^{j}>1$, indicating that sector $i$ 's share in country $j$ 's exports in period $t$ is larger than in the group of reference countries $J$, country $j$ is said to have a revealed comparative advantage in sector $i$. 
Table 5 Summary information for Balassa index (BI), 1980 - 2000

\begin{tabular}{|c|c|c|c|c|c|c|}
\hline \multicolumn{7}{|l|}{ a. Benchmark } \\
\hline Statistic & All & AUS & FRA & NLD & GBR & USA \\
\hline \# Observations & 2,100 & 420 & 420 & 420 & 420 & 420 \\
\hline Mean & 0.94 & 0.85 & 0.89 & 1.03 & 0.96 & 0.98 \\
\hline Median & 0.79 & 0.33 & 0.82 & 0.72 & 0.87 & 0.91 \\
\hline Variance & 0.59 & 1.37 & 0.14 & 0.87 & 0.30 & 0.25 \\
\hline Minimum & 0.00 & 0.00 & 0.19 & 0.12 & 0.12 & 0.14 \\
\hline Maximum & 6.44 & 6.44 & 2.06 & 5.62 & 3.09 & 2.87 \\
\hline$\# \mathrm{BI}>1$ & 676 & 98 & 164 & 104 & 139 & 171 \\
\hline Share BI > 1 (\%) & 32.2 & 23.3 & 39.0 & 24.8 & 33.1 & 40.7 \\
\hline \multicolumn{7}{|l|}{ b. $M \& A$ acquirer } \\
\hline Statistic & All & AUS & FRA & NLD & GBR & USA \\
\hline \# Observations & 3,462 & 189 & 257 & 137 & 1,446 & 1,433 \\
\hline Mean & 1.08 & 1.24 & 1.06 & 1.10 & 1.04 & 1.10 \\
\hline Median & 1.00 & 0.77 & 1.13 & 0.89 & 0.98 & 1.01 \\
\hline Variance & 0.19 & 1.34 & 0.10 & 0.39 & 0.11 & 0.11 \\
\hline Minimum & 0.01 & 0.01 & 0.29 & 0.13 & 0.16 & 0.19 \\
\hline Maximum & 6.44 & 6.44 & 1.75 & 3.89 & 2.58 & 2.48 \\
\hline$\# \mathrm{BI}>1$ & 1,783 & 61 & 150 & 48 & 673 & 851 \\
\hline Share BI > 1 (\%) & 51.5 & 32.3 & 58.4 & 35.0 & 46.5 & 59.4 \\
\hline \multicolumn{7}{|l|}{ c. $M \& A$ target } \\
\hline Statistic & All & AUS & FRA & NLD & GBR & USA \\
\hline \# Observations & 3,462 & 261 & 416 & 212 & 878 & 1,695 \\
\hline Mean & 1.08 & 1.12 & 1.00 & 1.14 & 1.04 & 1.11 \\
\hline Median & 1.00 & 0.71 & 0.96 & 0.90 & 0.99 & 1.03 \\
\hline Variance & 0.24 & 1.29 & 0.11 & 0.62 & 0.12 & 0.12 \\
\hline Minimum & 0.00 & 0.00 & 0.29 & 0.12 & 0.15 & 0.15 \\
\hline Maximum & 6.44 & 6.44 & 1.75 & 5.62 & 2.43 & 2.54 \\
\hline$\# \mathrm{BI}>1$ & 1,800 & 76 & 200 & 79 & 421 & 1,024 \\
\hline Share BI > 1 (\%) & 52.0 & 29.1 & 48.1 & 37.3 & 47.9 & 60.4 \\
\hline
\end{tabular}

For M\&A acquirer and target in the period 2001-2005 the (most recent) BI of 2000 was used. 
We have annual observations available for the period 1980-2000. Our group of reference countries $J$ consists of the OECD countries. The core of our paper analyzes a subset of data, consisting of 20 2-digit SIC sectors $\left(I^{\prime} \subset I\right)$ and 5 individual OECD countries $\left(J^{\prime} \subset J\right)$, see Appendix I. ${ }^{15}$ Table 5 provides summary statistics on the distribution of the Balassa index for the five countries separately and combined for three different data selections, namely (a) the benchmark distribution for all sectors in our data set for all years, (b) the distribution of the Balassa index for the acquirer of an M\&A, and (c) similarly for the target of an M\&A. Note that the number of observations is lower for the benchmark distribution in Table 5 (2,100 in panel (a) as compared to 3,462 in panels (b) and (c)). The reason for this is that the benchmark distribution for the Balassa index for our 5 countries counts each sector only once whereas for the acquirer (target) Balassa index distribution (panels b and c) the number of acquiring (target) firms is the unit of observation. This explains why in panel a the number of observations is the same for all 5 countries (420), but not in panels b and c with the USA and UK having far more than 420 observations because of the large number of US and UK acquiring and target firms.

A few observations on these statistics can readily be made.

- The distribution differs per country. The benchmark median for the USA (0.91), for example, is almost three times that for Australia (0.33). Similarly, the benchmark share of sectors with a Balassa index above 1 is higher for the USA (40.7 percent) than for Australia (23.3 percent) and the Netherlands (24.8 percent).

- The Balassa index is higher for the acquirer than the benchmark. For each individual country and for the group as a whole, the mean, median, and the share of sectors with a Balassa index above 1 is higher for the M\&A acquirer distribution than for the benchmark distribution.

- The Balassa index is higher for the target than the benchmark. Again, for all countries the mean, median, and the share of sectors with a Balassa index above 1 is higher for the M\&A target distribution than for the benchmark distribution.

\footnotetext{
${ }^{15}$ When calculating the Balassa index for the respective sub-groups, we do include all exports of goods and services for an individual country (sectors $I$ ) and relate this to the exports of all reference countries (OECD countries $J$ ), see equation (5).
} 
Figure 4 Relationship between M\&As and revealed comparative advantage

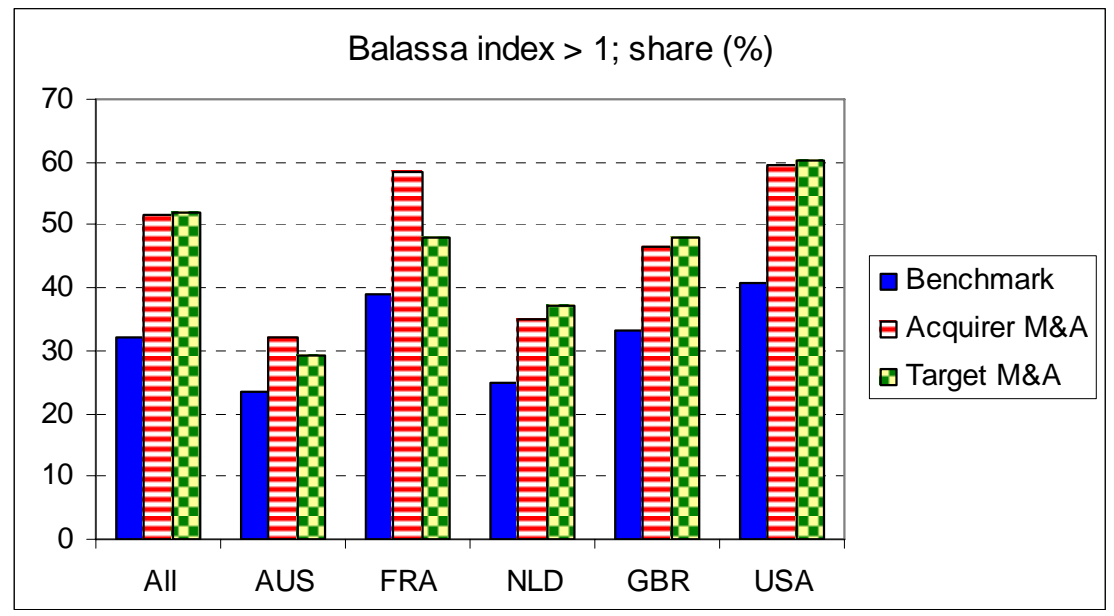

These findings are illustrated for the share of sectors with a Balassa index above 1 in Figure 4. Note that the Balassa index appears to be higher for both acquirer and target. To some extent this represents a problem for the GOLE model as the acquirer is thought to be a more efficient firm than the target. To some extent this is in line with the theoretical model, as the difference between the acquirer's and the target's efficiency should not be too large. ${ }^{16}$ We will present estimation results for both acquirers and targets. Figure 4 visualizes the model's main prediction in terms of hypothesis 1 . For acquiring firms we must test, as Figure 4 suggests, whether it is indeed true that the cross-sector distribution of the Balassa index when sectors are weighted by the number of acquiring firms lies significantly above the corresponding distribution when sector are unweighted (as with the benchmark in Figure 4).

The disadvantage of focusing on a few summary statistics, as given in Table 5 and Figure 4, is that it ignores the majority of the information available in the underlying distribution functions. Although these distributions of the Balassa index for the individual countries and the group as a whole are not known, we can apply the distribution-free Harmonic Mass index procedure developed by Hinloopen and van Marrewijk (2005) to test formally if any pair of distribution functions is identical. ${ }^{17}$ With a 5 per cent significance level, this leads to the following formal conclusions (see Appendix II):

\footnotetext{
${ }^{16}$ Again, a similar prediction holds for Bertrand and Zitouna (2006).

${ }^{17}$ This is a non-parametric method to compare two distributions of data, in order to see whether the distributions differ, see for a motivation of this method: http://people.few.eur.nl/vanmarrewijk/pdf/marrewijk/ti\%20dp\%202005\%20122.pdf
} 
- The benchmark distribution differs significantly from the M\&A acquirer and target distributions, both in the aggregate and for individual countries.

- The M\&A acquirer distribution does not differ significantly from the M\&A target distributions, both in the aggregate and for individual countries, with the exception of France.

- The distributions for individual countries differs significantly, with the exception of France - USA in the benchmark.

Figure 5 Comparison of comparative advantage distributions, 1980-2005
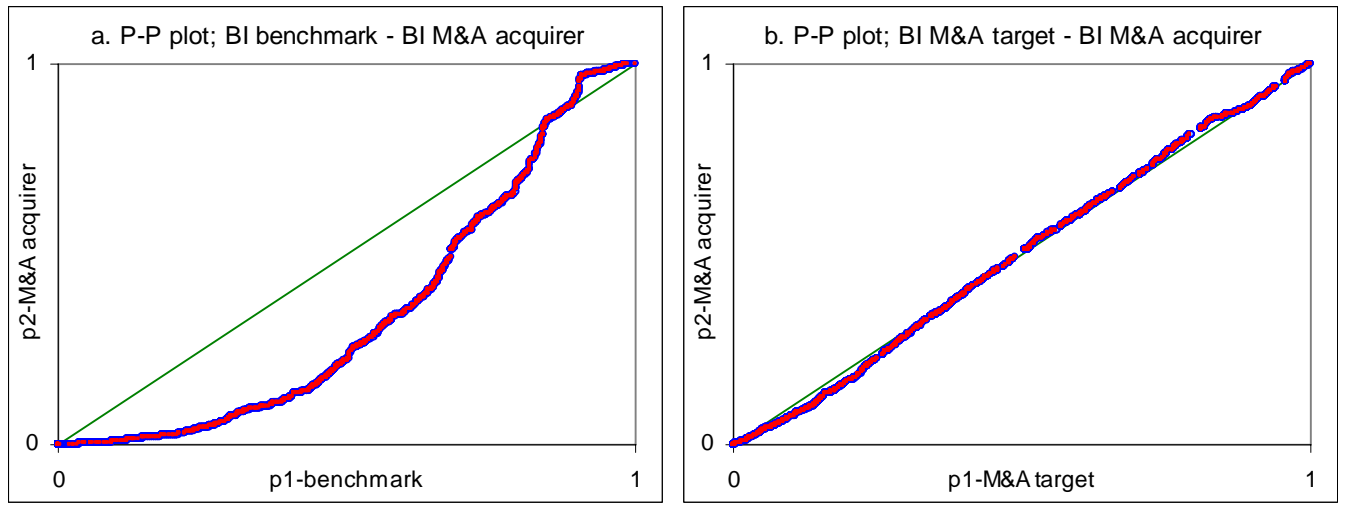

These conclusions are illustrated for the aggregate distributions in Figure 5 using P-P (probability - probability) plots, a method for comparing distribution functions used as the basis for the Harmonic mass index which, if the underlying distributions are identical, results in a plot coinciding with the diagonal. Clearly, the deviation between the plot and the diagonal is large if we compare the benchmark with the acquirer's distribution and small if we compare the acquirer's and the target's distribution.

\subsection{Waves}

We finally turn to the introduction of merger waves in order to be in a position to test hypotheses 2A-D in the next sections. To get a first indication of M\&A waves, we let $N_{i}^{k}(t)$ denote the number of M\&As in sector $i \in I^{\prime}$ in the $k$ year period immediately preceding period time $t$ (for all countries $j \in J^{\prime}$ combined). We denote their sum by $N^{k}(t)$, that is $N^{k}(t) \equiv \sum_{i \in I^{\prime}} N_{i}^{k}(t)$. Figure 6a depicts the evolution over time of $N^{1}(t)$ and $N^{2}(t)$, that is the number of M\&As in the previous one and two years, respectively. There have been two clear waves for all sectors combined, namely 
around 1990-1991 and around 1999-2001 (this is most evident over a two-year period). Figures $6 \mathrm{~b}$ and $6 \mathrm{c}$, similarly, depict the evolution over time within a one-year and two-year period for some individual sectors from the acquirer's perspective. ${ }^{18}$ Although the sector peaks coincide largely with the aggregate peaks around 1990 and 2000, there are also sector-specific peaks, for example at the end of 2004 for SIC 28 (Chemicals and allied products) and around 1995-1996 for sic 20 (Food and kindred products).

Figure 6 M\&A waves
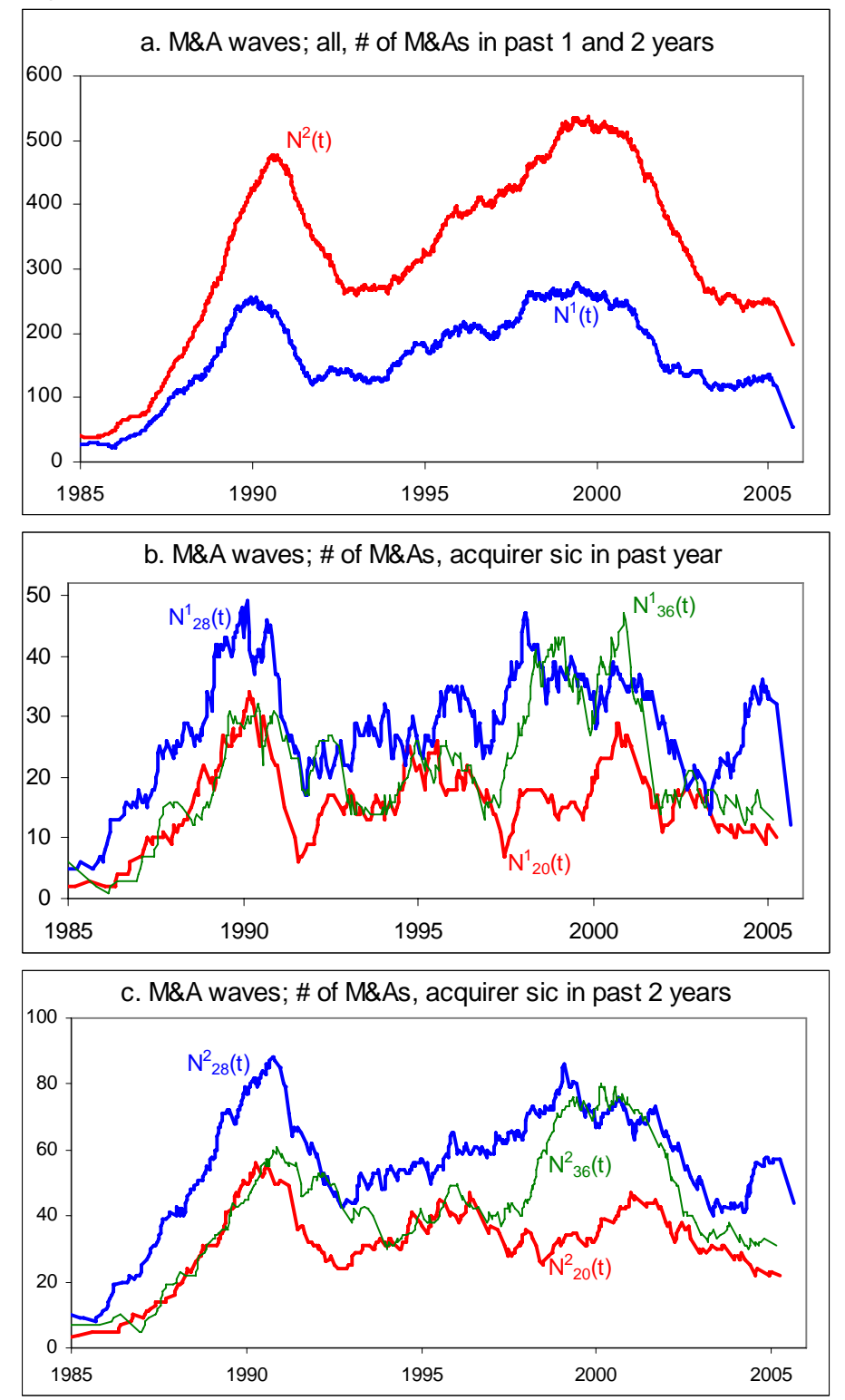

\footnotetext{
${ }^{18}$ At the sector level we can distinguish between the number of M\&As in the acquirer's sector and in the target's sector in the k-year period preceding time t. The difference is generally small and disappears in the aggregate (when we sum over all sectors).
} 


\section{Deciding on the estimation model}

To test the hypotheses 1A-B and 2A-D outlined at the end of section 3, we analyze the number of $M \& A s$ undertaken by firms in a specific country and sector for the period 1980-2004, both from an acquirer's and a target's perspective. As there are 5 countries, 20 sectors, and 25 years, this leads to a total of 2,500 acquiring and 2,500 target observations. Taking country- and sector-specific effects into account, our focus is thus on the impact of revealed comparative advantage, as measured by the Balassa index, and M\&A waves. Our dependent variable is a discrete counting variable ( $y_{i}$, is the number of M\&As in a specific country and sector in a given year). In the tables with estimation results in the remainder of the paper the following holds. From an acquiring perspective, the dependent variable is the number of M\&As acquired by a specific country and sector in a given year. The wave variables then refer to the number of acquisitions in the year before or the two years before (for all countries and sectors and for the country and sector in question). From a target perspective, the dependent variable is the number of M\&A targets in a specific country and sector in a given year. The wave variables then refer to the number of targets in the year before or the two years before (again for all countries and sectors and for the specific country and sector in question). With respect to revealed comparative advantage, two Balassa index results are reported. The variable BI simply reports the value of the Balassa index for the specific country and sector in that year. Since this index differs significantly between countries (section 4), we constructed Balassa index-country interactions, to deal with these differences. The $B I_{A U}$ variable, for example, reports the value of the Balassa index for Australia for the sector under consideration if the country is Australia, and zero otherwise. ${ }^{19}$

An obvious first candidate model for the estimations is the Poisson regression model (see e.g. Greene, 2003) and to use this model for both acquirer and target firms. For the Poisson model the conditional density of $y_{i}$ given $x_{i}$ is:

$$
f\left(y_{i} \mid x_{i}, \beta\right)=e^{-m\left(x_{i}, \beta\right)} m\left(x_{i}, \beta\right)^{y_{i}} / y_{i} !
$$

where $m\left(x_{i}, \beta\right)=E\left(y_{i} \mid x_{i}, \beta\right)=\exp \left(x_{i}^{\prime} \beta\right)$ is the conditional mean.

\footnotetext{
${ }^{19}$ Note that we do not include the $\mathrm{BI}_{\mathrm{US}}$ variable to avoid (almost) overidentification.
} 
In Appendix III we present the estimation results based upon the Poisson estimates. The most important restriction of the Poisson model is the equality of the conditional mean and variance, see below. The Poisson estimates in Appendix III provide support for the hypothesis that acquiring firms are operative in sectors with a strong comparative advantage, but not for the hypothesis that target firms are operative in sectors with a weak comparative advantage. On the contrary, target firms also seem to operate in relatively strong sectors, although the effect is not as clear-cut as for acquiring firms (and not significant for France and the UK). Of the various merger wave variables, the global number of M\&As for all sectors in the previous year is significant and positive in all Poisson estimations. Rather than discussing these Poisson results in more detail, we want to point out that the Poisson equation is misspecified as there is overdispersion in the data, because the conditional mean and variance are not equal (which is a condition to use the Poisson equation). Table 6 reports the results of two tests of this restriction, based on the work of Cameron and Trivedi (1990) and Wooldridge (1990).

Table 6 Poisson restriction tests; shape estimates $\eta^{2}$, (standard errors in parentheses)

\begin{tabular}{|c|c|c|c|c|}
\hline & \multicolumn{2}{|c|}{ acquiring perspective } & \multicolumn{2}{|c|}{ target perspective } \\
\hline & $\begin{array}{l}\text { Table A.3 } \\
\text { column } 2 \\
\end{array}$ & $\begin{array}{l}\text { Table A.3 } \\
\text { column } 3 \\
\end{array}$ & $\begin{array}{l}\text { Table A.3 } \\
\text { column } 4 \\
\end{array}$ & $\begin{array}{l}\text { Table A.3 } \\
\text { column } 5\end{array}$ \\
\hline Cameron-Trivedi test & $\begin{array}{c}0.0826^{* * *} \\
(0.0043)\end{array}$ & $\begin{array}{c}0.0827^{* * *} \\
(0.0043)\end{array}$ & $\begin{array}{c}0.0640^{* * *} \\
(0.0048)\end{array}$ & $\begin{array}{c}0.0710^{* * *} \\
(0.0048)\end{array}$ \\
\hline Wooldridge test & $\begin{array}{c}0.1101^{* * *} \\
(0.0249)\end{array}$ & $\begin{array}{c}0.1117^{* * *} \\
(0.0251)\end{array}$ & $\begin{array}{l}0.1128^{* *} \\
(0.0520)\end{array}$ & $\begin{array}{l}0.1171^{* *} \\
(0.0526)\end{array}$ \\
\hline
\end{tabular}

An extension of the Poisson model is provided by the more flexibile negative binomial model, see for example Bloningen (1997), Coughlin and Segev (2000), and Barry, et al. (2003), for which the following moment conditions hold:

$$
E\left(y_{i} \mid x_{i}, \beta\right)=m\left(x_{i}, \beta\right) ; \quad \operatorname{var}\left(y_{i} \mid x_{i}, \beta\right)=m\left(x_{i}, \beta\right)\left(1+\eta^{2} m\left(x_{i}, \beta\right)\right)
$$

Note that $\eta^{2}$ (referred to as the "shape" parameter) is a measure of the extent to which the conditional variance exceeds the conditional mean. In effect, the Cameron Trivedi and Wooldridge tests reported in Table 6 are estimates of the parameter $\eta^{2}$. All estimates of $\eta^{2}$ in Table 6 are highly significant, such that there is indeed 
overdispersion in the data. We therefore use a two-step negative binomial Quasi Maximum Likelihood estimation, termed the quasi-generalized pseudo-maximum likelihood estimator by Gourieroux, et al. (1984a,b), by using the estimates of the Wooldridge tests $\left(\hat{\eta}^{2}=0.11\right)$ in the negative binomial estimates. We used the robust Quasi-Maximum Likelihood (QML) estimation procedure in the sequel as it produces more consistent estimates of the parameters of a correctly specified conditional mean than the Maximum Likelihood (ML) estimation procedure, even if the distribution is incorrectly specified, combined with the Huber/White robust covariance estimation procedure. All reported estimations have include country- and sector fixed effects.

\section{Firm level estimation results}

\subsection{Negative binomial estimates for the acquirer}

In this sub-section we present our estimation results for the acquiring firm, see Tables 7A and 7B, which give the estimation results for the Balassa index and the Balassacountry interactions respectively. In both cases we first give the estimation results for the Balassa index and waves variables separately. In the "both" column the Balassa and wave variables are combined. The "selection" column gives the results after a sequential elimination procedure of the most insignificant variables (lowest probabilities) in the "both" specification. This leads to the inclusion of only those variables that were at least significant at the 10 percent level. ${ }^{20}$ Our discussion focuses on these estimates (last column of Table 7A). With respect to hypothesis 1A, we find clear and strong supporting evidence that acquiring firms are active in sectors in which the country has a strong comparative advantage. As for the various merger waves, we find no support for a global sector effect (hypothesis 2A) and a positive global total effect (hypothesis 2B). ${ }^{21}$ At the country level, we find a positive countrysector effect (hypothesis 2C) and a mixed country-total effect (hypothesis 2D; namely a positive 1-year effect and a negative 2-year effect). As will become clear below, these results are very robust with respect to the impact of comparative advantage and the positive wave effects (global-total and country-sector), whereas the country-total wave effect is usually negative (rather than mixed).

\footnotetext{
${ }^{20}$ Details of the intermediate results are available from the authors upon request.

${ }^{21}$ The wave variables introduce a problem of multi-collinearity. A possible solution to this is to construct a 'principal component' of waves. We choose not to do so, to illustrate the effects of different types of waves as clearly as possible.
} 
Table 7A Negative Binomial Count; QML (parameter =0.11), acquiring perspective (standard errors in parentheses), [incidence rate ratio in square brackets]

\begin{tabular}{|c|c|c|c|c|}
\hline & Balassa & Waves & Both & Select \\
\hline \multicolumn{5}{|l|}{ Balassa index } \\
\hline BI & $\begin{array}{c}0.3578^{* * *} \\
(0.0558)\end{array}$ & & $\begin{array}{l}0.2549^{* * *} \\
(0.0521)\end{array}$ & $\begin{array}{l}0.2573^{* * *}[22] \\
\quad(0.0518)\end{array}$ \\
\hline \multicolumn{5}{|l|}{ Waves } \\
\hline all-sec $_{1}$ & & $\begin{array}{c}0.0042 \\
(0.0100)\end{array}$ & $\begin{array}{c}0.0036 \\
(0.0098)\end{array}$ & \\
\hline all-sec $_{1+2}$ & & $\begin{array}{c}-0.0050 \\
(0.0059)\end{array}$ & $\begin{array}{c}-0.0030 \\
(0.0059)\end{array}$ & \\
\hline all-tot ${ }_{1}$ & & $\begin{array}{c}0.0070^{* * *} \\
(0.0019)\end{array}$ & $\begin{array}{l}0.0070^{* * *} \\
(0.0019)\end{array}$ & $\begin{array}{l}0.0065^{* * *}[71] \\
\quad(0.0006)\end{array}$ \\
\hline all-tot ${ }_{1+2}$ & & $\begin{array}{l}-0.0001 \\
(0.0010)\end{array}$ & $\begin{array}{c}-0.0002 \\
(0.0010)\end{array}$ & \\
\hline co-sec $_{1}$ & & $\begin{array}{c}-0.0024 \\
(0.0168)\end{array}$ & $\begin{array}{c}-0.0010 \\
(0.0166)\end{array}$ & \\
\hline co-sec $_{1+2}$ & & $\begin{array}{c}0.0257^{* * *} \\
(0.0098)\end{array}$ & $\begin{array}{l}0.0194^{* *} \\
(0.0097)\end{array}$ & $\begin{array}{l}0.0176^{* * *}[10] \\
\quad(0.0048)\end{array}$ \\
\hline co-tot $_{1}$ & & $\begin{array}{c}0.0074^{*} \\
(0.0041)\end{array}$ & $\begin{array}{c}0.0073^{*} \\
(0.0041)\end{array}$ & $\begin{array}{c}0.0087^{* * *}[34] \\
(0.0026)\end{array}$ \\
\hline co-tot $_{1+2}$ & & $\begin{array}{c}-0.0056^{* *} \\
(0.0023)\end{array}$ & $\begin{array}{l}-0.0052^{* *} \\
(0.0022)\end{array}$ & $\begin{array}{c}-0.0059^{* * *}[-33] \\
(0.0013)\end{array}$ \\
\hline co-sec fixed effects & yes & yes & yes & yes \\
\hline Log likelihood & $-3,010$ & $-2,498$ & $-2,485$ & $-2,485$ \\
\hline Restr log likelihood & $-32,418$ & $-29,993$ & $-29,993$ & $-29,993$ \\
\hline LR statistic & $58,816^{* * *}$ & $54,990^{* * *}$ & $55,017^{* * *}$ & $55,016^{* * *}$ \\
\hline LR index (pseudo- $\mathrm{R}^{2}$ ) & 0.907 & 0.917 & 0.917 & 0.917 \\
\hline \# observations & 2,500 & 2,300 & 2,300 & 2,300 \\
\hline
\end{tabular}

To gauge the economic importance of the various estimates in Table 7A, beyond the observation that the estimated coefficient differs significantly from zero, the last column of the table reports the incidence rate ratio (irr). For variable $k$ with standard deviation $s d_{k}$ and estimated coefficient $\beta_{k}$ this ratio is defined in equation (6). It 
indicates by what percentage the expected number of M\&A-acquisitions increases if the variable in question rises by one standard deviation.

$$
\operatorname{irr}_{k}=100 \times\left(e^{\beta_{k} \times s d_{k}}-1\right)
$$

The table shows that a one-standard deviation increase in the Balassa index raises the expected number of M\&A-acquisitions by 22 percent. A similar increase in the global-total merger wave variable (1-year) is more important as it raises the expected number of M\&A-acquisitions by 71 percent. The country-sector effect is weaker with an expected increase of 10 percent. $^{22}$

Table 7B provides similar estimates as Table 7A, but now based on the Balassa index - country interaction specification (which takes into consideration that the BI index differs significantly between countries, see section 4). Again, we find strong support for hypothesis $1 \mathrm{~A}$ as the BI-country effects are significantly positive for all countries. A one-standard deviation increase in the Balassa index leads to an expected increase in the number of M\&A-acquisitions of 23, 22, 15, and 11 percent in Australia, France, the Netherlands, and the UK, respectively (see the last column of the table). The results for hypothesis 2 on the merger wave effects in terms of estimated coefficients, significance, and economic impact are comparable to those of the simpler specification in Table 7A. In both specifications (Tables 7A and 7B), the estimated significance is robust with respect to the specification when the comparative advantage (Balassa) effect and the wave effects are taken separately or both are included together. The estimated coefficients do change, however, when both effects are taken into consideration simultaneously. This holds particularly for the Balassa index variables and less so for the wave variables. All estimated specifications in tables 7A and 7B are highly significant and explain a large share of the variance in the number of M\&A-acquisitions (highly significant LR statistic and an LR index [pseudo- $\mathrm{R}^{2}$ ] of 0.907 or higher).

\footnotetext{
${ }^{22}$ The 1-year and (1+2)-year reported incidence rate ratio's for the country-total merger waves $(+34$ and -33 percent) are ceteris paribus. By construction these two variables are related and the total effect when this is taken into consideration is small.
} 
Table 7B Negative Binomial Count; QML (parameter = 0.11), acquiring perspective (standard errors in parentheses), [incidence rate ratio in square brackets]

\begin{tabular}{|c|c|c|c|c|}
\hline & Balassa & Waves & Both & Select \\
\hline \multicolumn{5}{|l|}{ Balassa index } \\
\hline $\mathrm{BI}_{\mathrm{AU}}$ & $\begin{array}{c}0.3914^{* * *} \\
(0.0696)\end{array}$ & & $\begin{array}{l}0.3231^{* * *} \\
(0.0674)\end{array}$ & $\begin{array}{l}0.3264^{* * *}[23] \\
\quad(0.0671)\end{array}$ \\
\hline $\mathrm{BI}_{\mathrm{FR}}$ & $\begin{array}{l}0.5006^{* *} \\
(0.2340)\end{array}$ & & $\begin{array}{l}0.5106^{* *} \\
(0.2186)\end{array}$ & $\begin{array}{l}0.5154^{* *}[22] \\
\quad(0.2185)\end{array}$ \\
\hline $\mathrm{BI}_{\mathrm{NT}}$ & $\begin{array}{l}0.2863^{* *} \\
(0.1312)\end{array}$ & & $\begin{array}{l}0.2378^{* *} \\
(0.1209)\end{array}$ & $\begin{array}{l}0.2383^{* *}[15] \\
\quad(0.1219)\end{array}$ \\
\hline $\mathrm{BI}_{\mathrm{UK}}$ & $\begin{array}{c}0.4948^{* * *} \\
(0.1319)\end{array}$ & & $\begin{array}{l}0.2366^{* *} \\
(0.1162)\end{array}$ & $\begin{array}{l}0.2388^{* *}[11] \\
\quad(0.1163)\end{array}$ \\
\hline \multicolumn{5}{|l|}{ Waves } \\
\hline all-sec 1 & & $\begin{array}{c}0.0042 \\
(0.0100)\end{array}$ & $\begin{array}{c}0.0037 \\
(0.0099)\end{array}$ & \\
\hline all-sec $1+2$ & & $\begin{array}{l}-0.0050 \\
(0.0059)\end{array}$ & $\begin{array}{l}-0.0033 \\
(0.0059)\end{array}$ & \\
\hline all-tot ${ }_{1}$ & & $\begin{array}{l}0.0070^{* * *} \\
(0.0019)\end{array}$ & $\begin{array}{l}0.0069^{* * *} \\
(0.0019)\end{array}$ & $\begin{array}{l}0.0064^{* * *}[71] \\
\quad(0.0006)\end{array}$ \\
\hline all-tot $_{1+2}$ & & $\begin{array}{l}-0.0001 \\
(0.0010)\end{array}$ & $\begin{array}{l}-0.0002 \\
(0.0010)\end{array}$ & \\
\hline co-sec $_{1}$ & & $\begin{array}{c}-0.0024 \\
(0.0168)\end{array}$ & $\begin{array}{l}-0.0017 \\
(0.0167)\end{array}$ & \\
\hline co-sec $_{1+2}$ & & $\begin{array}{c}0.0257^{* * *} \\
(0.0098)\end{array}$ & $\begin{array}{l}0.0210^{* *} \\
(0.0097)\end{array}$ & $\begin{array}{l}0.0187^{* * *}[11] \\
\quad(0.0048)\end{array}$ \\
\hline co-tot $_{1}$ & & $\begin{array}{l}0.0074^{*} \\
(0.0041)\end{array}$ & $\begin{array}{l}0.0074^{*} \\
(0.0041)\end{array}$ & $\begin{array}{l}0.0086^{* * *}[34] \\
\quad(0.0026)\end{array}$ \\
\hline co-tot $_{1+2}$ & & $\begin{array}{c}-0.0056^{* *} \\
(0.0023)\end{array}$ & $\begin{array}{l}-0.0053^{* *} \\
(0.0022)\end{array}$ & $\begin{array}{c}-0.0059^{* * *}[-33] \\
(0.0013)\end{array}$ \\
\hline co-sec fixed effects & yes & yes & yes & yes \\
\hline Log likelihood & $-3,009$ & $-2,498$ & $-2,482$ & $-2,483$ \\
\hline Restr log likelihood & $-32,418$ & $-29,993$ & $-29,993$ & $-29,993$ \\
\hline LR statistic & $58,818^{* * *}$ & $54,990^{* * *}$ & $55,022^{* * *}$ & $55,022^{* * *}$ \\
\hline LR index (pseudo- $\mathrm{R}^{2}$ ) & 0.907 & 0.917 & 0.917 & 0.917 \\
\hline \# observations & 2,500 & 2,300 & 2,300 & 2,300 \\
\hline
\end{tabular}

tot $=$ total, $\mathrm{co}=$ country, sec $=$ sector, sub-index $1=$ one year ago, sub-index $1+2=1$ and 2 years ago . *** = statistically significant at $1 \%$ level, $* * 5 \%$ level, and * $10 \%$ level. Huber/White st errors. 


\subsection{Negative binomial estimates for the target}

Using a similar approach as in sub-section 6.1 from an acquiring perspective, we now discuss our main results from a target perspective. Table 8A provides estimation results on the simple Balassa index approach while Table $8 \mathrm{~B}$ gives the results for the Balassa - country interactions.

Table 8A Negative Binomial Count; QML (parameter = 0.11), target perspective (standard errors in parentheses), [incidence rate ratio in square brackets]

\begin{tabular}{|c|c|c|c|c|}
\hline & Balassa & Waves & Both & Select \\
\hline \multicolumn{5}{|l|}{ Balassa index } \\
\hline $\mathrm{BI}$ & $\begin{array}{c}0.2836^{* * *} \\
(0.0545)\end{array}$ & & $\begin{array}{l}0.1647^{* *} \\
(0.0523)\end{array}$ & $\begin{array}{l}0.1708^{* * *}[14] \\
\quad(0.0514)\end{array}$ \\
\hline \multicolumn{5}{|l|}{ Waves } \\
\hline all-sec 1 & & $\begin{array}{l}-0.0082 \\
(0.0091)\end{array}$ & $\begin{array}{l}-0.0081 \\
(0.0090)\end{array}$ & $\begin{array}{c}-0.0103^{* *}[-9] \\
(0.0050)\end{array}$ \\
\hline all-sec $_{1+2}$ & & $\begin{array}{l}-0.0021 \\
(0.0053)\end{array}$ & $\begin{array}{l}-0.0011 \\
(0.0053)\end{array}$ & \\
\hline all-tot ${ }_{1}$ & & $\begin{array}{l}0.0098^{* * *} \\
(0.0018)\end{array}$ & $\begin{array}{l}0.0098^{* * *} \\
(0.0018)\end{array}$ & $\begin{array}{c}0.0086^{* * *}[105] \\
(0.0006)\end{array}$ \\
\hline all-tot $_{1+2}$ & & $\begin{array}{l}-0.0006 \\
(0.0010)\end{array}$ & $\begin{array}{l}-0.0007 \\
(0.0010)\end{array}$ & \\
\hline co-sec $_{1}$ & & $\begin{array}{c}0.0278 \\
(0.0184)\end{array}$ & $\begin{array}{c}0.0278 \\
(0.0180)\end{array}$ & $\begin{array}{l}0.0466^{* * *}[14] \\
(0.0091)\end{array}$ \\
\hline co-sec $_{1+2}$ & & $\begin{array}{c}0.0165 \\
(0.0113)\end{array}$ & $\begin{array}{c}0.0125 \\
(0.0113)\end{array}$ & \\
\hline co-tot $_{1}$ & & $\begin{array}{l}-0.0008 \\
(0.0036)\end{array}$ & $\begin{array}{l}-0.0008 \\
(0.0036)\end{array}$ & \\
\hline co-tot $_{1+2}$ & & $\begin{array}{l}-0.0041^{* *} \\
(0.0021)\end{array}$ & $\begin{array}{l}-0.0038^{*} \\
(0.0021)\end{array}$ & $\begin{array}{c}-0.0042^{* * *}[-23] \\
(0.0009)\end{array}$ \\
\hline co-sec fixed effects & yes & yes & yes & yes \\
\hline Log likelihood & $-3,234$ & $-2,687$ & $-2,680$ & $-2,682$ \\
\hline Restr log likelihood & $-32,241$ & $-29,815$ & $-29,815$ & $-29,815$ \\
\hline LR statistic & $58,014^{* * *}$ & $54,256^{* * *}$ & $54,269^{* * *}$ & $54,266^{* * *}$ \\
\hline LR index (pseudo-R ${ }^{2}$ ) & 0.900 & 0.910 & 0.910 & 0.910 \\
\hline \# observations & 2,500 & 2,300 & 2,300 & 2,300 \\
\hline
\end{tabular}


Focusing attention first on hypothesis $1 \mathrm{~B}$ (target firms operate in sectors with a low revealed comparative advantage) we can conclude that this hypothesis is soundly rejected. Not only do we not find evidence that target firms are active in weak sectors, but to the contrary we find evidence that target firms are also active in strong sectors. This effect from a target perspective is weaker than from an acquirer perspective since (i) the positive Balassa - country interaction effect for the target does not hold for France and the UK (Table 8B) and (ii) the simple Balassa effect is weaker for the target than for the acquirer (compare Tables 7A and 8A). Regarding the latter, a onestandard deviation increase in the Balassa index leads to a 22 percent increase in the expected number of M\&A-acquisitions and a 14 percent increase in the expected number of M\&A targets. The rejection of hypothesis $1 \mathrm{~B}$ contradicts with a strict interpretation of the two-country GOLE model. We thus label this result the 'target paradox'. The next section argues that our empirical results can be explained in a heterogenous firms, multi-country extension of the GOLE model.

Turning now to the merger waves hypotheses, we find that both the simple Balassa approach and the Balassa - country interaction approach lead to similar results, namely a negative global-sector effect (hypothesis 2A), a positive global-total effect (hypothesis 2B), a positive country-sector effect (hypothesis 2C), and a negative country-total effect (hypothesis 2D). More generally (see the estimates to come and the overview in section 9), this illustrates that if we find a significant effect at the global level (for the sector in question or all sectors together) we find the opposite effect at the country level (or not significant, or mixed over the two lags). In terms of economic impact, the global-total wave effect is the most important, where a onestandard deviation increase raises the expected number of M\&A targets by 105 percent in Table 8A and by 110 percent in Table 8B. All estimated specifications in tables $8 \mathrm{~A}$ and $8 \mathrm{~B}$ are highly significant and explain a large share of the variance in the number of M\&A-targets (highly significant LR statistic and an LR index [pseudo-R ${ }^{2}$ ] of 0.900 or higher). 
Table 8B Negative Binomial Count; QML (parameter =0.11), target perspective (standard errors in parentheses), [incidence rate ratio in square brackets]

\begin{tabular}{|c|c|c|c|c|}
\hline & Balassa & Waves & Both & Select \\
\hline \multicolumn{5}{|l|}{ Balassa index } \\
\hline $\mathrm{BI}_{\mathrm{AU}}$ & $\begin{array}{c}0.3218^{* * *} \\
(0.0716)\end{array}$ & & $\begin{array}{c}0.2238^{* * *} \\
(0.0649)\end{array}$ & $\begin{array}{l}0.2211^{* * *}[15] \\
\quad(0.0649)\end{array}$ \\
\hline $\mathrm{BI}_{\mathrm{FR}}$ & $\begin{array}{c}0.0287 \\
(0.2097)\end{array}$ & & $\begin{array}{c}-0.0185 \\
(0.1885)\end{array}$ & \\
\hline $\mathrm{BI}_{\mathrm{NT}}$ & $\begin{array}{c}0.4014^{* * *} \\
(0.1329)\end{array}$ & & $\begin{array}{l}0.3136^{* *} \\
(0.1249)\end{array}$ & $\begin{array}{l}0.3162^{* *}[21] \\
\quad(0.1258)\end{array}$ \\
\hline $\mathrm{BI}_{\mathrm{UK}}$ & $\begin{array}{l}0.3340^{* *} \\
(0.1397)\end{array}$ & & $\begin{array}{c}0.1427 \\
(0.1267)\end{array}$ & \\
\hline \multicolumn{5}{|l|}{ Waves } \\
\hline all-sec 1 & & $\begin{array}{c}-0.0082 \\
(0.0091)\end{array}$ & $\begin{array}{c}-0.0081 \\
(0.0090)\end{array}$ & \\
\hline all-sec $1+2$ & & $\begin{array}{l}-0.0021 \\
(0.0053)\end{array}$ & $\begin{array}{l}-0.0016 \\
(0.0053)\end{array}$ & $\begin{array}{c}-0.0066^{* *}[-11] \\
(0.0027)\end{array}$ \\
\hline all-tot ${ }_{1}$ & & $\begin{array}{l}0.0098^{* * *} \\
(0.0018)\end{array}$ & $\begin{array}{c}0.0098^{* * *} \\
(0.0018)\end{array}$ & $\begin{array}{l}0.0089^{* * *}[110] \\
\quad(0.0006)\end{array}$ \\
\hline all-tot $_{1+2}$ & & $\begin{array}{l}-0.0006 \\
(0.0010)\end{array}$ & $\begin{array}{l}-0.0006 \\
(0.0010)\end{array}$ & \\
\hline co-sec 1 & & $\begin{array}{c}0.0278 \\
(0.0184)\end{array}$ & $\begin{array}{c}0.0278 \\
(0.0180)\end{array}$ & \\
\hline $\mathrm{co}^{-\mathrm{sec}_{1+2}}$ & & $\begin{array}{c}0.0165 \\
(0.0113)\end{array}$ & $\begin{array}{c}0.0141 \\
(0.0112)\end{array}$ & $\begin{array}{l}0.0290^{* * *}[17] \\
\quad(0.0056)\end{array}$ \\
\hline co-tot $_{1}$ & & $\begin{array}{l}-0.0008 \\
(0.0036)\end{array}$ & $\begin{array}{c}-0.0009 \\
(0.0035)\end{array}$ & \\
\hline co-tot $1+2$ & & $\begin{array}{l}-0.0041^{* *} \\
(0.0021)\end{array}$ & $\begin{array}{l}-0.0039^{*} \\
(0.0021)\end{array}$ & $\begin{array}{c}-0.0047^{* * *}[-25] \\
(0.0009)\end{array}$ \\
\hline co-sec fixed effects & yes & yes & yes & yes \\
\hline Log likelihood & $-3,232$ & $-2,687$ & $-2,676$ & $-2,678$ \\
\hline Restr log likelihood & $-32,241$ & $-29,815$ & $-29,815$ & $-29,815$ \\
\hline LR statistic & $58,017^{* * *}$ & $54,256^{* * *}$ & $54,278^{* * *}$ & $54,273^{* * *}$ \\
\hline LR index (pseudo- ${ }^{2}$ ) & 0.900 & 0.910 & 0.910 & 0.910 \\
\hline \# observations & 2,500 & 2,300 & 2,300 & 2,300 \\
\hline
\end{tabular}

tot $=$ total, $\mathrm{co}=$ country, sec $=$ sector, sub-index $1=$ one year ago, sub-index $1+2=1$ and 2 years ago . $* * *=$ statistically significant at $1 \%$ level, $* * 5 \%$ level, and * $10 \%$ level. Huber/White st errors. 


\section{Explaining the target paradox}

In section 6 we have established that (i) both acquiring and target firms tend to be operative in a country's strong sectors and (ii) this effect is more pronounced for acquiring firms than for target firms. We can explain this apparent 'target paradox' if we extend the GOLE model to a multi-country setting and simultaneously allow for firm heterogeneity within countries. For simplicity, we just consider three countries, A, B, and C, and discuss the implications of a more general setting. Based on Melitz (2003), firm heterogeneity is modeled as new entrants drawing a productivity parameter from a country-sector-specific distribution function. For the sector under consideration, we will assume that country A is strong, country C is weak, and country B is in between. Modeling this as a mean-shifting process, the average ex ante production costs will be lowest for country A, intermediate for country B, and highest for country C, see Figure 7.

Figure 7 Production trade and M\&As in a multi-country setting

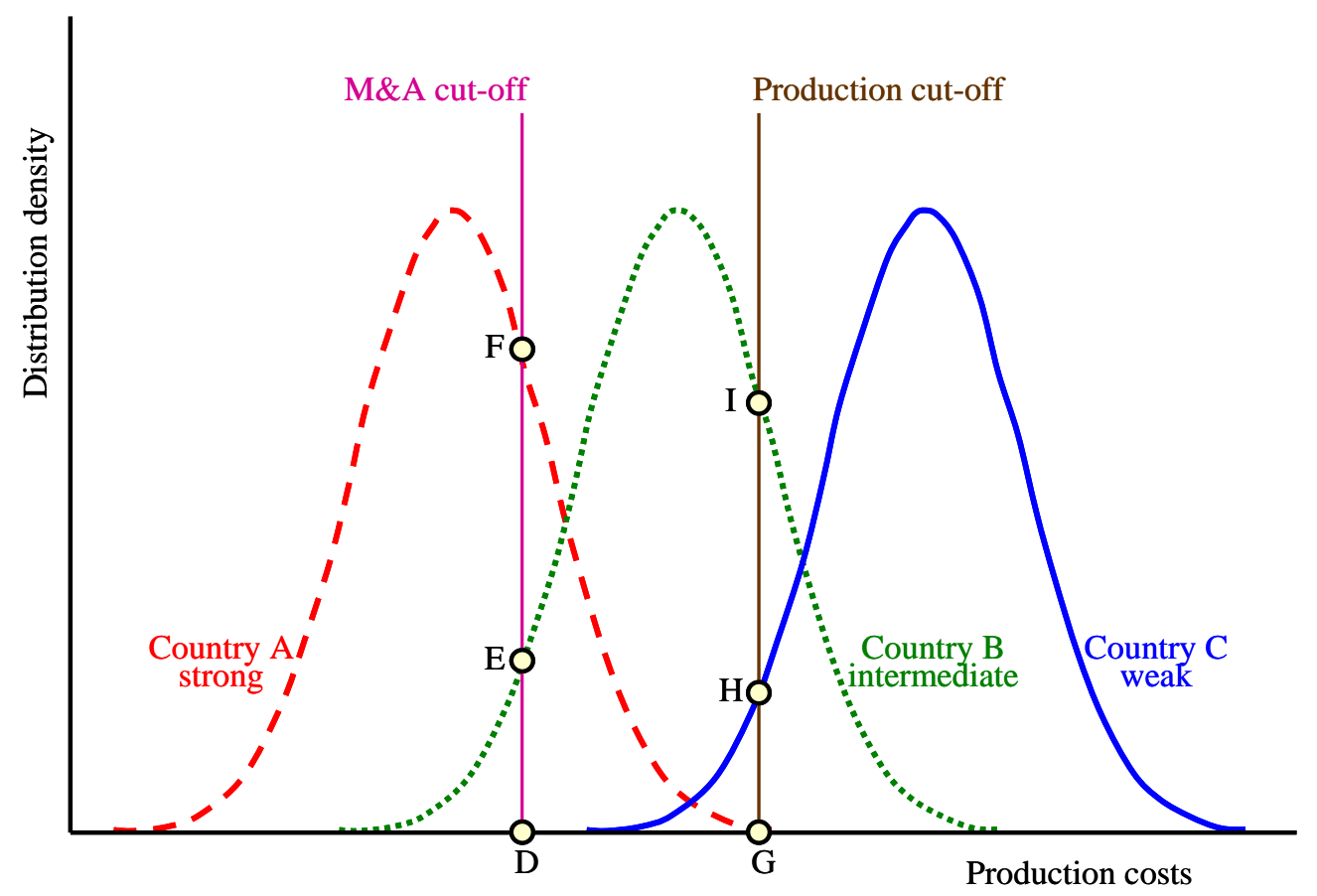

In the Neary (2007) model two cut-offs are important. First, if production costs are too high, the firm is not viable and will exit the market. Second, if production costs are too low, a firm is too profitable, and thus too costly, to take over. Assuming, for simplicity, that these cut-offs are the same for the three countries, we label these the 
Production cut-off and the M\&A cut-off in Figure 7, respectively. Neary shows that the M\&A cut-off is below the Production cut-off, as shown. We discuss the implications in terms of production, trade, and M\&As for each country in turn.

Strong country A. Most firms in the strong country A have costs below the Production cut-off (point G) and therefore do not exit the market. The firms with costs below the M\&A cut-off (the share of country A firms to the left of DF) are too profitable to take over. Instead, these firms are potential acquirers of other firms. The country-A firms in between the M\&A cut-off and the Production cut-off (points DFG) are potential targets for other firms. All firms that do not exit the market produce and export goods, as reflected by a high Balassa index. In short, strong country A has a large share of potential acquiring firms and potential target firms, as well as a high Balassa index.

Weak country $C$. Almost all firms in the weak country $C$ have costs above the Production cut-off (to the right of $\mathrm{GH}$ ) and therefore exit the market. The few remaining firms are (in our example) potential targets for takeover. In view of their high costs, the production and export level is low and so is the Balassa index. Note that if country $\mathrm{C}$ is weaker still (the distribution shifts sufficiently further to the right) there would be no potential target firms to take over and the Balassa index would be zero. Empirical information on the Balassa index shows that countries export only in a sub-set of sectors and have a revealed comparative advantage (BI > 1) in only about one-third of the sectors with positive export flows, see Hinloopen and van Marrewijk (2001, 2008). One should therefore imagine many countries to look like the weak country $\mathrm{C}$ with no or only a few potential target firms and a low Balassa index.

Intermediate country B. A substantial number of the firms in the intermediate country B has costs above the Production cut-off (to the right of GI) and will therefore exit the market. The remaining firms can be subdivided into two groups. The more productive firms have costs below the M\&A cut-off (to the left of DE) and are therefore potential acquirers of other firms. The group of firms in between the two cut-offs (points DEIG) will produce and export goods and are potential M\&A targets. Although the extent of comparative advantage is less strong than for country A, country B firms still play a major role in the global export market for this good and has a higher Balassa index than weak countries, like country C. In short, intermediate country B 
has a large share of potential target firms but also a substantial share of potential acquiring firms, as well as a fairly high Balassa index.

Based on the above observations, what we should expect, therefore, from a multicountry heterogeneous firm extension of the GOLE model, is that (i) both acquiring and target firms are active in strong sectors (high Balassa index), (ii) this effect is more pronounced for acquiring than for target firms, and (iii) these observations are caused by the fact that countries with weak sectors (low Balassa index) have no or only a few potential target firms to take over. Our estimation results above are in accordance with these findings.

\section{Robustness}

\subsection{Estimation results for horizontal M\&As}

In our discussion of Figure 3 in sub-section 4.3 we noted that the GOLE model is in fact only concerned with intra-industry M\&As. The model simply makes no predictions about inter-industry M\&As. Assuming that each of our 20 SIC2 sectors represents a single industry, we re-estimated all equations for horizontal M\&As only, that is for those M\&As where the acquiring and target firm belong to the same SIC2 sector. The share of horizontal M\&As in our overall data set (after taking care of the concordance issue) is 64.5 percent. Based on the results for the Wooldridge estimate we use shape parameter of $\hat{\eta}^{2}=0.13$ in the subsequent negative binomial count estimations. ${ }^{23}$ For the sake of brevity, we only present the estimation results for the "select" specifications, see Table 9. The results are comparable with those reported in sections 6.1 and 6.2 for the full sample. From the acquiring perspective the only exception is that the Balassa-country interaction variable for France is no longer significant. This also means that in terms of hypotheses $1 \mathrm{~A}$ and $1 \mathrm{~B}$, we again find confirmation that acquiring firms come from sectors that have a revealed comparative advantage, and that this holds in a weaker sense for target firms. The results for merger waves are also largely comparable to those shown before, see the overview and discussion in section 9.

${ }^{23}$ Details available from the authors upon request. 
Table 9 Negative Binomial Count for horizontal M\&As;

QML (parameter $=0.13$ ), (standard errors in parentheses), select

\begin{tabular}{|c|c|c|c|c|}
\hline & \multicolumn{2}{|c|}{ acquiring perspective } & \multicolumn{2}{|c|}{ target perspective } \\
\hline BI & $\begin{array}{c}0.2677^{* * *} \\
(0.0607)\end{array}$ & & $\begin{array}{c}0.2202^{* * *} \\
(0.0587)\end{array}$ & \\
\hline $\mathrm{BI}_{\mathrm{AU}}$ & & $\begin{array}{c}0.3658^{* * *} \\
(0.0793)\end{array}$ & & $\begin{array}{c}0.2844^{* * *} \\
(0.0745)\end{array}$ \\
\hline $\mathrm{BI}_{\mathrm{NT}}$ & & $\begin{array}{l}0.2837^{* *} \\
(0.1240)\end{array}$ & & $\begin{array}{c}0.4863^{* * *} \\
(0.1242)\end{array}$ \\
\hline $\mathrm{BI}_{\mathrm{UK}}$ & & $\begin{array}{c}0.2379^{+} \\
(0.1492)\end{array}$ & & \\
\hline $\begin{array}{l}\text { Waves } \\
\quad \text { all-sec } 1+2\end{array}$ & $\begin{array}{l}-0.0090^{* *} \\
(0.0044)\end{array}$ & $\begin{array}{c}-0.0090^{* *} \\
(0.0044)\end{array}$ & & \\
\hline all-tot ${ }_{1}$ & $\begin{array}{c}0.0130^{* * *} \\
(0.0011)\end{array}$ & $\begin{array}{c}0.0129^{* * *} \\
(0.0011)\end{array}$ & $\begin{array}{l}0.0146^{* * *} \\
(0.0020)\end{array}$ & $\begin{array}{c}0.0146^{* * *} \\
(0.0019)\end{array}$ \\
\hline all-tot $_{1+2}$ & & & $\begin{array}{l}-0.0020^{*} \\
(0.0011)\end{array}$ & $\begin{array}{l}-0.0020^{*} \\
(0.0011)\end{array}$ \\
\hline co-sec $_{1+2}$ & $\begin{array}{c}0.0284^{* * *} \\
(0.0077)\end{array}$ & $\begin{array}{l}0.0284^{* * *} \\
(0.0077)\end{array}$ & $\begin{array}{l}0.0302^{* * *} \\
(0.0072)\end{array}$ & $\begin{array}{c}0.0298^{* * *} \\
(0.0072)\end{array}$ \\
\hline \multicolumn{5}{|l|}{ co-tot 1} \\
\hline co-tot $_{1+2}$ & $\begin{array}{c}-0.0055^{* * *} \\
(0.0015)\end{array}$ & $\begin{array}{c}-0.0054^{* * *} \\
(0.0015)\end{array}$ & $\begin{array}{c}-0.0048^{* * *} \\
(0.0018)\end{array}$ & $\begin{array}{c}-0.0048^{* * *} \\
(0.0018)\end{array}$ \\
\hline co-sec fixed effects & yes & yes & yes & yes \\
\hline Log likelihood & $-1,981$ & $-1,979$ & $-2,084$ & $-2,077$ \\
\hline Restr log likelihood & $-22,105$ & $-22,105$ & $-22,023$ & $-22,023$ \\
\hline LR statistic & $40,248^{* * *}$ & $40,253^{* * *}$ & $39,879^{* * *}$ & $39,891^{* * *}$ \\
\hline LR index (pseudo-R²) & 0.910 & 0.910 & 0.905 & 0.906 \\
\hline \# observations & 2,300 & 2,300 & 2,300 & 2,300 \\
\hline
\end{tabular}


Table 10 Pure cross-border negative binomial count; $Q M L$ (parameter $=0.10$ ) (standard errors in parentheses), select

\begin{tabular}{|c|c|c|c|c|}
\hline & \multicolumn{2}{|c|}{ acquirer } & \multicolumn{2}{|c|}{ target } \\
\hline BI & $\begin{array}{l}0.3150^{* * *} \\
(0.0668)\end{array}$ & & $\begin{array}{c}0.1788^{* * *} \\
(0.0600)\end{array}$ & \\
\hline $\mathrm{BI}_{\mathrm{AU}}$ & & $\begin{array}{l}0.2712^{* *} \\
(0.1110)\end{array}$ & & $\begin{array}{c}0.1665^{*} \\
(0.0865)\end{array}$ \\
\hline $\mathrm{BI}_{\mathrm{FR}}$ & & $\begin{array}{l}0.5534^{* *} \\
(0.2498)\end{array}$ & & \\
\hline $\mathrm{BI}_{\mathrm{NT}}$ & & $\begin{array}{c}0.2086^{+} \\
(0.1416)\end{array}$ & & $\begin{array}{c}0.3529^{* * *} \\
(0.1247)\end{array}$ \\
\hline $\mathrm{BI}_{\mathrm{UK}}$ & & $\begin{array}{l}0.3666^{* *} \\
(0.1446)\end{array}$ & & $\begin{array}{c}0.2483^{*} \\
(0.1500)\end{array}$ \\
\hline $\begin{array}{l}\text { Waves } \\
\quad \text { all-sec } 1\end{array}$ & & & $\begin{array}{l}-0.0121^{*} \\
(0.0067)\end{array}$ & $\begin{array}{c}-0.0135^{* *} \\
(0.0067)\end{array}$ \\
\hline all-tot 1 & & & $\begin{array}{l}0.0105^{* * *} \\
(0.0009)\end{array}$ & $\begin{array}{c}0.0106^{* * *} \\
(0.0009)\end{array}$ \\
\hline all-tot ${ }_{1+2}$ & $\begin{array}{l}0.0035^{* * *} \\
(0.0004)\end{array}$ & $\begin{array}{c}0.0035^{* * *} \\
(0.0004)\end{array}$ & & \\
\hline co-sec $_{1}$ & & & $\begin{array}{c}0.0613^{* * *} \\
(0.0134)\end{array}$ & $\begin{array}{c}0.0656^{* * *} \\
(0.0132)\end{array}$ \\
\hline co-sec $_{1+2}$ & $\begin{array}{l}0.0233^{* * *} \\
(0.0072)\end{array}$ & $\begin{array}{c}0.0253^{* * *} \\
(0.0073)\end{array}$ & & \\
\hline co-tot $_{1}$ & $\begin{array}{c}0.0313^{* * *} \\
(0.0036)\end{array}$ & $\begin{array}{c}0.0312^{* * *} \\
(0.0036)\end{array}$ & & \\
\hline co-tot $_{1+2}$ & $\begin{array}{c}-0.0152^{* * *} \\
(0.0022)\end{array}$ & $\begin{array}{c}-0.0153^{* * *} \\
(0.0022)\end{array}$ & $\begin{array}{c}-0.0045^{* * *} \\
(0.0014)\end{array}$ & $\begin{array}{c}-0.0047^{* * *} \\
(0.0014)\end{array}$ \\
\hline co-sec fixed effects & yes & yes & yes & yes \\
\hline Log likelihood & $-2,107$ & $-2,109$ & $-2,324$ & $-2,322$ \\
\hline Restr log likelihood & $-33,626$ & $-33,626$ & $-33,386$ & $-33,386$ \\
\hline LR statistic & $63,040^{* * *}$ & $63,035^{* * *}$ & $62,124^{* * *}$ & $62,129^{* * *}$ \\
\hline LR index (pseudo-R²) & 0.937 & 0.937 & 0.930 & 0.930 \\
\hline \# observations & 2300 & 2300 & 2300 & 2300 \\
\hline
\end{tabular}




\subsection{Estimation results for pure cross-border M\&As}

As noted in section 4, the Thomson data set sometimes classifies M\&As as crossborder even though the headquarters of both acquirer and target are located in the same country. We stress again that Thomson does this only in a small percentage of such within-country cases (namely if there is an important reason to do so, for example if the part that is taken over is largely active in another country). Our main results presented in section 6 include such within-country cross-border M\&As. Obviously, such within-country M\&As, where we register acquirer and target within the same country, tend to increase the number of horizontal M\&As (see sub-section 8.1) and the link between acquirer and target in terms of revealed comparative advantage. As a second robustness check, we therefore focused on pure cross-border M\&As by excluding the within-country M\&As. The share of horizontal M\&As in our overall data set (after taking care of the concordance issue) is 69.7 percent.

As in section 8.1, we re-estimated all equations, but now for pure cross-border M\&As. The estimated shape parameter $\hat{\eta}^{2}=0.10$ in the subsequent negative binomial count estimations. Table 10 presents the "select” estimation results only. The results are very similar to those reported in sections 6.1 and 6.2 for the full sample. We again find confirmation that acquiring firms come from sectors that have a revealed comparative advantage, and that this holds in a weaker sense for target firms. The results for merger waves are also comparable, see the discussion in section 9.

\subsection{Further robustness checks}

As a way of providing further robustness checks, Appendix IV (see Tables A4 and A5 for the acquiring and target perspective, respectively) provides estimation results for the negative binominal count estimation (in each column for the resulting "select" specification) when we estimate the model for two sub-periods. The first sub-period, 1982-2000, is the period that coincides with the years for we which we have trade data to calculate the Balassa index. We used the most recent observation (year 2000) for the M\&As in the years 2001-2004 in the tables above in the main text. Ignoring the last three years of observations does not materially affect our results (see Tables A4 and A5). Sub-sample estimations for the second sub-period, 1985-2004, correct 
for the fact that US firms were over-represented in the Thomson data initially. Again, Tables A4 and A5 show that it does not affect our results for acquirers and targets, respectively, despite the more limited number of observations. The bottom line of these additional estimates is that our main findings are robust.

\section{Conclusions}

Traditionally, the modeling of mergers and acquisitions (M\&As) provides only a partial understanding of cross-border M\&As, which are thought to be related to economy-wide differences between countries. Peter Neary (2003, 2007) combines general equilibrium trade theory with imperfect markets and strategic behavior of firms to allow for the possibility of cross-border M\&As (the GOLE model). We test two implications of this model, namely regarding strong and weak sectors and regarding merger waves. Our test procedure combines two large data sets, namely the bilateral sectoral international trade data compiled by Feenstra et al. (2005) and the Thomson data on individual M\&As.

The bilateral GOLE model does not incorporate within-country firm heterogeneity and focuses on global merger waves. The model predicts that firms in a country where a sector is strong take over firms in the country where this sector is weak. We operationalize a country's strong and weak sectors based on the frequently used method of revealed comparative advantage (Balassa index). Hypothesis 1A argues that acquiring firms are active in sectors with a high Balassa index, while hypothesis $1 \mathrm{~B}$ argues that target firms are active in sectors with a low Balassa index. We test these hypotheses both using a simple Balassa index test and using a test that incorporates the fact that the Balassa distribution is country-specific (Balassa-country interaction). Our data allows us to identify both global and country-specific merger waves, for all sectors taken together (all) and for the sector under consideration. Hypotheses 2A-2D identify these four possible merger waves. We analyze the data both from an acquirer perspective and from a target perspective. Our main robustness checks focus on horizontal M\&As only and on pure cross-border M\&As. ${ }^{24}$ Table 11 summarizes our main findings from these various perspectives, see Tables 7-10 for further details.

\footnotetext{
${ }^{24}$ Secundary checks look at different time periods.
} 
Table 11 Overview of support for hypotheses and estimation results

\begin{tabular}{|c|c|c|c|c|c|c|}
\hline \multicolumn{7}{|c|}{ a. Simple Balassa index test } \\
\hline \multirow[b]{2}{*}{ Hypothesis } & \multicolumn{3}{|c|}{ acquiring perspective } & \multicolumn{3}{|c|}{ target perspective } \\
\hline & all & horiz. & pure & all & horiz. & pure \\
\hline \multicolumn{7}{|l|}{1 Balassa index BI } \\
\hline A acquirer high BI & yes & yes & yes & - & - & - \\
\hline $\mathrm{B}$ target low BI & - & - & - & no & no & no \\
\hline \multicolumn{7}{|l|}{2 Waves $^{+}$} \\
\hline A global sector & no & minus & no & minus & no & minus \\
\hline B global all & plus & plus & plus & plus & mixed & plus \\
\hline C country sector & plus & plus & plus & plus & plus & plus \\
\hline D country all & mixed & minus & minus & minus & minus & minus \\
\hline
\end{tabular}

b. Balassa index - country interactions test

\begin{tabular}{|c|c|c|c|c|c|c|}
\hline \multirow[b]{2}{*}{ Hypothesis } & \multicolumn{3}{|c|}{ acquiring perspective } & \multicolumn{3}{|c|}{ target perspective } \\
\hline & all & horiz. & pure & all & horiz. & pure \\
\hline $\begin{array}{l}1 \text { Balassa index BI } \\
\text { A acquirer high BI } \\
\text { B target low BI }\end{array}$ & $\begin{array}{c}\text { yes } \\
-\end{array}$ & $\begin{array}{c}\text { yes }^{*} \\
-\end{array}$ & $\begin{array}{c}\text { yes } \\
-\end{array}$ & no & $\begin{array}{c}- \\
\text { no }\end{array}$ & - \\
\hline $\begin{array}{l}2 \text { Waves } \\
\text { A global sector } \\
\text { B global all } \\
\text { C country sector } \\
\text { D country all }\end{array}$ & $\begin{array}{l}\text { no } \\
\text { plus } \\
\text { plus } \\
\text { mixed }\end{array}$ & $\begin{array}{l}\text { minus } \\
\text { plus } \\
\text { plus } \\
\text { minus }\end{array}$ & $\begin{array}{l}\text { no } \\
\text { plus } \\
\text { plus } \\
\text { minus }\end{array}$ & $\begin{array}{l}\text { minus } \\
\text { plus } \\
\text { plus } \\
\text { minus }\end{array}$ & $\begin{array}{l}\text { no } \\
\text { mixed } \\
\text { plus } \\
\text { minus }\end{array}$ & $\begin{array}{l}\text { minus } \\
\text { plus } \\
\text { plus } \\
\text { minus }\end{array}$ \\
\hline
\end{tabular}

We find strong and consistent support for hypothesis 1A (acquiring firms operate in strong sectors), but not for hypothesis $1 \mathrm{~B}$ (target firms operate in weak sectors). In fact, we find support for the opposite effect: target firms also operate in strong sectors, although the effect is less pronounced than for acquiring firms. We label this finding the 'target paradox'. As other studies before us, we find that merger waves are very important. The detailed structure of our data allows us to be more specific. In terms of economic importance, the dominant wave variable by far is the positive global-all effect, indicating that M\&A waves are an economy-wide, global phenomenon. Of secundary economic importance at the country level, there is a positive country-sector effect and a negative country-all effect. 
To explain the above-mentioned target paradox, we extend the GOLE model to a multi-country setting and simultaneously allow for firm heterogeneity within countries. We then show that we should expect that (i) both acquiring and target firms are active in strong sectors (high Balassa index), (ii) this effect is more pronounced for acquiring than for target firms, and (iii) these observations are caused by the fact that countries with weak sectors (low Balassa index) have no or only a few potential target firms to take over. Our estimation results are in accordance with these findings.

\section{References}

Andrade, G., M. Mitchell, and E. Stafford (2001), "New evidence and perspectives on mergers,” Journal of Economic Perspectives, 15(2): 103-120.

Balassa, B. (1989), “'Revealed’ Comparative Advantage Revisited,” In: B.Balassa (ed.), Comparative Advantage , Trade Policy and Economic Development, New York University Press, New York: 63-79.

Barba Navaretti, G., and A.J. Venables (2004), Multinational firms in the world economy, Princeton University Press, Princeton.

Barry, F., H. Görg, and E. Strobl (2003), “Foreign direct investment, agglomerations, and demonstration effects: an empirical investigation," Review of World Economics (Weltwirtschaftliches Archiv) 139(4): 583-600.

Bertrand, O., and H. Zitouna (2006), “Trade liberalization and industrial restructuring: the role of cross-border mergers and acquisitions," Journal of Economics and Management Strategy 15(2): 479-515.

Björkman, I., G.K. Stahl, and E. Vaara (2007), “Cultural differences and capability transfer in cross-border acquisitions: the mediating roles of capability complementarity, absorptive capacity, and social integration," Journal of International Business Studies 38: 658-672.

Bloningen, B.A. (1997), "Firm-specific assets and the link between exchange rates and foreign direct investments,” The American Economic Review 87 (3): 447-465.

Brakman, S., H. Garretsen, and C. van Marrewijk (2007), “Cross-border mergers and acquisitions: the facts as a guide for international economics,” in: G. Gregoriou and L. Renneboog (eds.), International Mergers and Acquisitions Activity since 1990: Recent Research and Quantitative Analysis, Academic Press/Elsevier, MA: 23-49. 
Cameron, A.C. and P.K. Trivedi (1990). "Regression-based Tests for Overdispersion in the Poisson Model," Journal of Econometrics 46: 347-364.

Coughlin, C.C., and E. Segev (2000), “Location determinants of new foreign-owned manufacturing plants,” Journal of Regional Science 40 (2): 323-351.

Dikova, D., and A. van Witteloostuijn (2007), "Foreign direct investment mode choice: entry and establishment modes in transition economies," Journal of International Business Studies38: 1013-1033.

Dixit, A. (2004), "Some reflections on theories and applications of monopolistic competition,” in: S. Brakman and B.J. Heijdra (eds.), The monopolistic competition revolution in retrospect, Cambridge University Press, Cambridge: 123-133.

Dornbusch, R., S. Fischer, and P.A. Samuelson (1977), “Comparative advantage, trade and payments in a Ricardian model with a continuum of goods," American Economic Review 67: 823-839.

Evenett, S.J. (2004), “The cross border mergers and acquisitions wave of the late 1990s,” in: R.E. Baldwin and L.A.Winters, Challenges to Globalization: Analyzing the Economics, The University of Chicago Press, Chicago and London.

Feenstra,, R.C., R.E. Lipsey, H. Deng, A.C. Ma, and H. Mo (2005), "World trade flows: 1962-2000,” NBER Working Paper Series, No. 11040, Cambridge, Mass.

Fridolfsson, S.-O., and J. Stennek (2005), "Why mergers reduce profits and raise share prices - a theory of preemptive mergers," Journal of the European Economic Association 3(5): 1083-1104.

Garita, G., and C. van Marrewijk (2008), "Countries of a feather flock together in cross-border M\&As,” Erasmus University Rotterdam, mimeo.

Gorton, G., M. Kahl, and R. Rosen (2005), “Eat or be eaten: a theory of mergers and merger waves,” NBER Working Paper 11364.

Greene (2003), Econometric analysis, Prentice Hall, Upper Saddle River, New Jersey.

Gourieroux, C., A. Monfort, and C. Trognon (1984a). "Pseudo-Maximum Likelihood Methods: Theory,” Econometrica, 52, 681-700.

Gourieroux, C., A. Monfort, and C. Trognon (1984b). "Pseudo-Maximum Likelihood Methods: Applications to Poisson Models,” Econometrica, 52, 701-720.

Gugler, K., D.C. Mueller, B.B. Yurtoglu, and C. Zulehner (2003), “The effects of mergers: an international comparison,” International Journal of Industrial Organization 21: 625-653. 
Gugler, K., D.C. Mueller, B.B. Yurtoglu (2004), “The determinants of merger waves,” mimeo, University of Vienna, Dept. of Economics.

Hejazi, W., and A.E. Safarian (1999), “Trade, Foreign Direct Investment, and R\&D Spillovers,” Journal of International Business Studies 30(3): 491-511.

Hinloopen, J., and C. van Marrewijk (2001), “On the empirical distribution of the Balassa index”, Review of World Economics (Weltwirtschaftliches Archiv) 137 (1): $1-35$.

Hinloopen, J., and C. van Marrewijk (2005), “The Harmonic Mass index: a new method for comparing distribution functions,” Tinbergen Institute, Working Paper.

Hinloopen, J. and C. van Marrewijjk (2008), "Empirical relevance of the Hillman condition for revealed comparative advantage: 10 stylized facts," Applied Economics, forthcoming.

Hofstede, G. (1980), Culture's Consequences, Sage, New York.

Kogut, B., and H. Singh (1988), “The effect of national culture on the choice of entry Mode,” Journal of International Business Studies, 19(3): 411-432.

Kuemmerle, W. (1999), “The Drivers of Foreign Direct Investment into Research and Development: An Empirical Investigation,” Journal of International Business Studies 30(1): 1-24.

Neary, J.P. (2003), “Globalization and market structure,” Journal of the European Economic Association 1: 245-271.

Neary, J.P. (2004), “Monopolistic competition and international trade theory,” in: S. Brakman and B.J. Heijdra (eds.), The monopolistic competition revolution in retrospect, Cambridge University Press, Cambridge.

Neary, J.P. (2007), “Cross-border mergers as instruments of comparative advantage,” Review of Economic Studies 74: 1229-1257.

Reuer, J.J., O. Shenkar, and R. Ragozzino (2004), “Mitigating risk in international mergers and acquisitions: the role of contingent payouts,” Journal of International Business Studies 35: 19-32.

Rossi, S., and P. Volpin (2004), "Cross-country determinants of mergers and acquisitions,” Journal of Financial Economics 74: 277-304.

Salant, S., S. Switzer, and R. Reynolds (1983), “Losses from horizontal merger: the effects of an exogenous change in industry structure on Cournot-Nash Equilibrium,” Quarterly Journal of Economics 98: 185-199. 
Schenk, H. (2002), "Fusies: omvang, reikwijdte en trends - een internationale inventarisatie,” in J. Bartel, R. van Frederikslust, H. Schenk (eds.), Fusies en acquisities, Elsevier: 37-62.

Shenkar, O. (2001), "Cultural Distance Revisited: Towards a More Rigorous Conceptualization and Measurement of Cultural Differences,” Journal of International Business Studies 32(3): 519-535.

Stiglitz, J. (2004), "Reflections on the state of the theory of monopolistic competition,” in: S. Brakman and B.J. Heijdra (eds.), The monopolistic competition revolution in retrospect, Cambridge University Press, Cambridge.

Wooldridge, J.M. (1990), “Quasi-Likelihood Methods for Count Data,” Chapter 8 in M.H. Pesaran and P. Schmidt (eds.) Handbook of Applied Econometrics, Volume 2, Malden, MA: Blackwell, 352-406. 


\section{Appendix I Country and sector description}

Table A.1 Overview of analyzed sectors $\left(I^{\prime} \subset I\right)$ and countries $\left(J^{\prime} \subset J\right)$

\begin{tabular}{|c|c|c|c|}
\hline \multicolumn{2}{|c|}{ a. Sectors $I^{\prime}$} & \multicolumn{2}{|c|}{ b. Countries $J^{\prime}$} \\
\hline SIC & Description & Code & Name \\
\hline 20 & Food and kindred products & AUS & Australia \\
\hline 21 & Tobacco products & FRA & France \\
\hline 22 & Textile mill products & NLD & Netherlands \\
\hline 23 & Apparel and other textile products & GBR & United Kingdom \\
\hline 24 & Lumber and wood products & USA & United States \\
\hline 25 & Furniture and fixtures & & \\
\hline 26 & Paper and allied products & & \\
\hline 27 & Printing and publishing & & \\
\hline 28 & Chemicals and allied products & & \\
\hline 29 & Petroleum and coal products & & \\
\hline 30 & Rubber and miscellaneous plastics products & & \\
\hline 31 & Leather and leather products & & \\
\hline 32 & Stone, clay, and glass products & & \\
\hline 33 & Primary metal industries & & \\
\hline 34 & Fabricated metal products & & \\
\hline 35 & Industrial machinery and equipment & & \\
\hline 36 & Electronic and other electric equipment & & \\
\hline 37 & Transport equipment & & \\
\hline 38 & Instruments and related products & & \\
\hline 39 & Miscellaneous manufacturing industries & & \\
\hline
\end{tabular}




\section{Appendix II}

Table A.2 Harmonic Mass index; bilateral comparison of distribution functions (shaded cells are identical at 5\% significance level)*

\begin{tabular}{|c|c|c|c|c|c|c|c|c|c|c|c|c|c|c|c|c|c|c|}
\hline & \multirow{2}{*}{\multicolumn{6}{|c|}{ Benchmark }} & \multicolumn{12}{|c|}{ Mergers \& Acquisitions } \\
\hline & & & & & & & & & & & acquirer & & & & & target & & \\
\hline & all & AUS & FRA & NLD & GBR & USA & acq & $\operatorname{tar}$ & AUS & FRA & NLD & GBR & USA & AUS & FRA & NLD & GBR & USA \\
\hline \multicolumn{19}{|l|}{ benchmark } \\
\hline All & 0.000 & 0.343 & 0.127 & 0.093 & 0.118 & 0.153 & 0.319 & 0.300 & 0.155 & 0.348 & 0.186 & 0.317 & 0.387 & 0.174 & 0.263 & 0.179 & 0.323 & 0.386 \\
\hline AUS & & 0.002 & 0.461 & 0.365 & 0.430 & 0.463 & 0.542 & 0.530 & 0.290 & 0.560 & 0.484 & 0.547 & 0.581 & 0.245 & 0.528 & 0.474 & 0.547 & 0.578 \\
\hline FRA & & & 0.002 & 0.175 & 0.094 & 0.075 & 0.266 & 0.247 & 0.271 & 0.291 & 0.140 & 0.251 & 0.336 & 0.295 & 0.187 & 0.125 & 0.253 & 0.336 \\
\hline NLD & & & & 0.002 & 0.186 & 0.202 & 0.397 & 0.367 & 0.176 & 0.414 & 0.233 & 0.416 & 0.459 & 0.184 & 0.339 & 0.221 & 0.418 & 0.450 \\
\hline USA & & & & & & 0.002 & 0.182 & 0.162 & 0.289 & 0.220 & 0.094 & 0.189 & 0.252 & 0.311 & 0.137 & 0.073 & 0.199 & 0.252 \\
\hline \multicolumn{19}{|l|}{ M\&As } \\
\hline Acq-all & & & & & & & 0.004 & 0.024 & 0.410 & 0.090 & 0.211 & 0.079 & 0.097 & 0.431 & 0.131 & 0.204 & 0.077 & 0.111 \\
\hline Tar-all & & & & & & & & 0.003 & 0.389 & 0.091 & 0.184 & 0.093 & 0.102 & 0.411 & 0.119 & 0.177 & 0.091 & 0.108 \\
\hline Acq-AUS & & & & & & & & & 0.019 & 0.417 & 0.315 & 0.423 & 0.458 & 0.072 & 0.368 & 0.298 & 0.424 & 0.451 \\
\hline Acq-FRA & & & & & & & & & & 0.014 & 0.228 & 0.108 & 0.130 & 0.438 & 0.131 & 0.230 & 0.108 & 0.128 \\
\hline Acq-NLD & & & & & & & & & & & 0.017 & 0.237 & 0.290 & 0.338 & 0.151 & 0.048 & 0.246 & 0.277 \\
\hline Tar-AUS & & & & & & & & & & & & & & 0.016 & 0.393 & 0.324 & 0.443 & 0.476 \\
\hline Tar-FRA & & & & & & & & & & & & & & & 0.012 & 0.153 & 0.137 & 0.191 \\
\hline Tar-NLD & & & & & & & & & & & & & & & & 0.013 & 0.244 & 0.272 \\
\hline Tar-GBR & & & & & & & & & & & & & & & & & 0.012 & 0.180 \\
\hline Tar-USA & & & & & & & & & & & & & & & & & & 0.010 \\
\hline \# obs & 2100 & 420 & 420 & 420 & 420 & 420 & 3462 & 3462 & 189 & 257 & 137 & 1446 & 1433 & 261 & 416 & 212 & 878 & 1695 \\
\hline
\end{tabular}

* Values in cells indicates Harmonic Mass index (exception: \# obs); the solid borders indicate the most relevant comparisons, as emphasized in the main text. 


\section{Appendix III}

Table A.3 Poisson Count; ML/QML (standard errors in parentheses)

\begin{tabular}{|c|c|c|c|c|}
\hline & \multicolumn{2}{|c|}{ acquiring perspective } & \multicolumn{2}{|c|}{ target perspective } \\
\hline BI & $\begin{array}{c}0.2730^{* * *} \\
(0.0514)\end{array}$ & & $\begin{array}{c}0.1903^{* * *} \\
(0.0504)\end{array}$ & \\
\hline $\mathrm{BI}_{\mathrm{AU}}$ & & $\begin{array}{c}0.3333^{* * *} \\
(0.0663)\end{array}$ & & $\begin{array}{c}0.2528^{* * *} \\
(0.0631)\end{array}$ \\
\hline $\mathrm{BI}_{\mathrm{FR}}$ & & $\begin{array}{c}0.5602^{* * *} \\
(0.2154)\end{array}$ & & $\begin{array}{c}0.0676 \\
(0.1886)\end{array}$ \\
\hline $\mathrm{BI}_{\mathrm{NT}}$ & & $\begin{array}{l}0.2637^{* *} \\
(0.1210)\end{array}$ & & $\begin{array}{c}0.3461^{* * *} \\
(0.1255)\end{array}$ \\
\hline $\mathrm{BI}_{\mathrm{UK}}$ & & $\begin{array}{l}0.2323^{* *} \\
(0.1180)\end{array}$ & & $\begin{array}{c}0.1551 \\
(0.1283)\end{array}$ \\
\hline $\begin{array}{l}\text { Waves } \\
\quad \text { all-sec } 1\end{array}$ & $\begin{array}{c}0.0040 \\
(0.0092)\end{array}$ & $\begin{array}{c}0.0040 \\
(0.0092)\end{array}$ & $\begin{array}{l}-0.0092 \\
(0.0088)\end{array}$ & $\begin{array}{c}-0.0090 \\
(0.0088)\end{array}$ \\
\hline all-sec $1+2$ & $\begin{array}{l}-0.0038 \\
(0.0055)\end{array}$ & $\begin{array}{l}-0.0042 \\
(0.0055)\end{array}$ & $\begin{array}{l}-0.0010 \\
(0.0051)\end{array}$ & $\begin{array}{c}-0.0015 \\
(0.0051)\end{array}$ \\
\hline all-tot $_{1}$ & $\begin{array}{c}0.0064^{* * *} \\
(0.0018)\end{array}$ & $\begin{array}{c}0.0063^{* * *} \\
(0.0019)\end{array}$ & $\begin{array}{c}0.0102^{* * *} \\
(0.0020)\end{array}$ & $\begin{array}{c}0.0102^{* * *} \\
(0.0019)\end{array}$ \\
\hline all-tot $_{1+2}$ & $\begin{array}{c}0.0000 \\
(0.0010)\end{array}$ & $\begin{array}{c}0.0000 \\
(0.0010)\end{array}$ & $\begin{array}{c}-0.0011 \\
(0.0011)\end{array}$ & $\begin{array}{c}-0.0010 \\
(0.0011)\end{array}$ \\
\hline co-sec $_{1}$ & $\begin{array}{l}-0.0063 \\
(0.0169)\end{array}$ & $\begin{array}{l}-0.0063 \\
(0.0169)\end{array}$ & $\begin{array}{c}0.0227 \\
(0.0168)\end{array}$ & $\begin{array}{c}0.0224 \\
(0.0171)\end{array}$ \\
\hline co-sec $_{1+2}$ & $\begin{array}{l}0.0200^{* *} \\
(0.0097)\end{array}$ & $\begin{array}{l}0.0215^{* *} \\
(0.0096)\end{array}$ & $\begin{array}{c}0.0094 \\
(0.0112)\end{array}$ & $\begin{array}{c}0.0109 \\
(0.0112)\end{array}$ \\
\hline co-tot $_{1}$ & $\begin{array}{l}0.0080^{* *} \\
(0.0040)\end{array}$ & $\begin{array}{l}0.0080^{* *} \\
(0.0040)\end{array}$ & $\begin{array}{l}-0.0020 \\
(0.0035)\end{array}$ & $\begin{array}{l}-0.0020 \\
(0.0035)\end{array}$ \\
\hline co-tot $_{1+2}$ & $\begin{array}{c}-0.0057^{* *} \\
(0.0022)\end{array}$ & $\begin{array}{c}-0.0058^{* * *} \\
(0.0022)\end{array}$ & $\begin{array}{l}-0.0029 \\
(0.0020)\end{array}$ & $\begin{array}{c}-0.0031 \\
(0.0020)\end{array}$ \\
\hline co-sec fixed effects & yes & yes & yes & yes \\
\hline Log likelihood & $-2,537$ & $-2,535$ & $-2,732$ & $-2,728$ \\
\hline Restr log likelihood & $-5,815$ & $-5,815$ & $-5,565$ & $-5,565$ \\
\hline LR statistic & $6,556^{* * *}$ & $6,560^{* * *}$ & $5,666^{* * *}$ & $5,675^{* * *}$ \\
\hline LR index (pseudo-R²) & 0.564 & 0.564 & 0.509 & 0.510 \\
\hline \# observations & 2,300 & 2,300 & 2,300 & 2,300 \\
\hline
\end{tabular}




\section{Appendix IV}

Table A.4 Acquiring robustness, negative binomial count; $Q M L$ (parameter $=0.11$ ) (standard errors in parentheses), select wave variables

\begin{tabular}{|c|c|c|c|c|}
\hline & \multicolumn{2}{|c|}{$1982-2000$} & \multicolumn{2}{|c|}{$1985-2004$} \\
\hline BI & $\begin{array}{c}0.2785^{* * *} \\
(0.0575)\end{array}$ & & $\begin{array}{c}0.2520^{* * *} \\
(0.0506)\end{array}$ & \\
\hline $\mathrm{BI}_{\mathrm{AU}}$ & & $\begin{array}{l}0.3528^{* * *} \\
(0.0731)\end{array}$ & & $\begin{array}{c}0.3194^{* * *} \\
(0.0648)\end{array}$ \\
\hline $\mathrm{BI}_{\mathrm{FR}}$ & & $\begin{array}{l}0.5031^{* *} \\
(0.2401)\end{array}$ & & $\begin{array}{l}0.5234^{* *} \\
(0.2158)\end{array}$ \\
\hline $\mathrm{BI}_{\mathrm{NT}}$ & & $\begin{array}{l}0.2765^{* *} \\
(0.1246)\end{array}$ & & $\begin{array}{l}0.2276^{*} \\
(0.1256)\end{array}$ \\
\hline $\mathrm{BI}_{\mathrm{UK}}$ & & $\begin{array}{l}0.1920^{+} \\
(0.1252)\end{array}$ & & $\begin{array}{c}0.19766^{*} \\
(0.1146)\end{array}$ \\
\hline $\begin{array}{l}\text { Waves } \\
\quad \text { all-tot }_{1}\end{array}$ & $\begin{array}{c}0.0074^{* * *} \\
(0.0007)\end{array}$ & $\begin{array}{l}0.0073^{* * *} \\
(0.0007)\end{array}$ & $\begin{array}{c}0.0047^{* * *} \\
(0.0007)\end{array}$ & $\begin{array}{c}0.0047^{* * *} \\
(0.0007)\end{array}$ \\
\hline co-sec $_{1+2}$ & $\begin{array}{c}0.0173^{* * *} \\
(0.0051)\end{array}$ & $\begin{array}{l}0.0185^{* * *} \\
(0.0051)\end{array}$ & $\begin{array}{c}0.0171^{* * *} \\
(0.0047)\end{array}$ & $\begin{array}{c}0.0183^{* * *} \\
(0.0047)\end{array}$ \\
\hline co-tot $_{1}$ & $\begin{array}{c}0.0079^{* * *} \\
(0.0030)\end{array}$ & $\begin{array}{l}0.0080^{* * *} \\
(0.0030)\end{array}$ & $\begin{array}{c}0.0101^{* * *} \\
(0.0025)\end{array}$ & $\begin{array}{c}0.0101^{* * *} \\
(0.0025)\end{array}$ \\
\hline co-tot $_{1+2}$ & $\begin{array}{c}-0.0062^{* * *} \\
(0.0015)\end{array}$ & $\begin{array}{c}-0.0063^{* * *} \\
(0.0015)\end{array}$ & $\begin{array}{c}-0.0064^{* * *} \\
(0.0013)\end{array}$ & $\begin{array}{c}-0.0065^{* * *} \\
(0.0013)\end{array}$ \\
\hline co-sec fixed effects & yes & yes & yes & yes \\
\hline Log likelihood & $-2,055$ & $-2,053$ & $-2,316$ & $-2,313$ \\
\hline Restr log likelihood & $-24,866$ & $-24,866$ & $-26,316$ & $-26,316$ \\
\hline LR statistic & $45,622^{* * *}$ & $45,626^{* * *}$ & $48,001^{* * *}$ & $48,006^{* * *}$ \\
\hline LR index (pseudo-R²) & 0.917 & 0.917 & 0.912 & 0.912 \\
\hline \# observations & 1,900 & 1,900 & 2,000 & 2,000 \\
\hline
\end{tabular}


Table A.5 Target robustness, negative binomial count; $Q M L$ (parameter $=0.11)$ (standard errors in parentheses), select wave variables

\begin{tabular}{|c|c|c|c|c|}
\hline & \multicolumn{2}{|c|}{$1982-2000$} & \multicolumn{2}{|c|}{$1985-2004$} \\
\hline BI & $\begin{array}{l}0.2010^{* * *} \\
(0.0557)\end{array}$ & & $\begin{array}{c}0.1707^{* * *} \\
(0.0505)\end{array}$ & \\
\hline $\mathrm{BI}_{\mathrm{AU}}$ & & $\begin{array}{c}0.2373^{* * *} \\
(0.0680)\end{array}$ & & $\begin{array}{c}0.2215^{* * *} \\
(0.0647)\end{array}$ \\
\hline $\mathrm{BI}_{\mathrm{FR}}$ & & $\begin{array}{c}0.0513 \\
(0.2089)\end{array}$ & & $\begin{array}{c}0.0020 \\
(0.1840)\end{array}$ \\
\hline $\mathrm{BI}_{\mathrm{NT}}$ & & $\begin{array}{c}0.3462^{* * *} \\
(0.1307)\end{array}$ & & $\begin{array}{l}0.3106^{* *} \\
(0.1221)\end{array}$ \\
\hline $\mathrm{BI}_{\mathrm{UK}}$ & & $\begin{array}{l}0.2071^{+} \\
(0.1351)\end{array}$ & & $\begin{array}{c}0.0901 \\
(0.1269)\end{array}$ \\
\hline $\begin{array}{l}\text { Waves } \\
\quad \text { all-sec } 1\end{array}$ & $\begin{array}{l}-0.0097^{*} \\
(0.0055)\end{array}$ & & $\begin{array}{c}-0.0129^{* *} \\
(0.0051)\end{array}$ & \\
\hline all-sec $_{1+2}$ & & $\begin{array}{c}-0.0082^{* * *} \\
(0.0030\end{array}$ & & $\begin{array}{c}-0.0091^{* * *} \\
(0.0028)\end{array}$ \\
\hline all-tot $_{1}$ & $\begin{array}{l}0.0092^{* * *} \\
(0.0007)\end{array}$ & $\begin{array}{c}0.0097^{* * *} \\
(0.0007)\end{array}$ & $\begin{array}{l}0.0069^{* * *} \\
(0.0007)\end{array}$ & $\begin{array}{c}0.0073^{* * *} \\
(0.0006)\end{array}$ \\
\hline co-sec $_{1}$ & $\begin{array}{l}0.0476^{* * *} \\
(0.0100)\end{array}$ & & $\begin{array}{l}0.0480^{* * *} \\
(0.0085)\end{array}$ & \\
\hline co-sec $_{1+2}$ & & $\begin{array}{c}0.0309^{* * *} \\
(0.0062)\end{array}$ & & $\begin{array}{c}0.0297^{* * *} \\
(0.0053)\end{array}$ \\
\hline co-tot $_{1+2}$ & $\begin{array}{c}-0.0046^{* * *} \\
(0.0009)\end{array}$ & $\begin{array}{c}-0.0052^{* * *} \\
(0.0010)\end{array}$ & $\begin{array}{c}-0.0038^{* * *} \\
(0.0009)\end{array}$ & $\begin{array}{c}-0.0042^{* * *} \\
0.0009\end{array}$ \\
\hline co-sec fixed effects & yes & yes & yes & yes \\
\hline Log likelihood & $-2,212$ & $-2,209$ & $-2,514$ & $-2,510$ \\
\hline Restr log likelihood & $-24,717$ & $-24,717$ & $-26,127$ & $-26,127$ \\
\hline LR statistic & $45,010^{* * *}$ & $45,017^{* * *}$ & $47,226^{* * *}$ & $47,233^{* * *}$ \\
\hline LR index (pseudo-R²) & 0.910 & 0.911 & 0.904 & 0.904 \\
\hline \# observations & 1,900 & 1,900 & 2,000 & 2,000 \\
\hline
\end{tabular}

